ADRIANA FRAGA COSTA SAMOS PARIS

\title{
O FATOR DE INIBIÇÃO DE MIGRAÇÃO DE MACRÓFAGOS (MIF) E A SOBREVIVÊNCIA DAS CÉLULAS DECIDUAIS. ESTUDO in vitro
}

Dissertação apresentada ao Programa de Pós-Graduação em Biologia Celular e Tecidual do Instituto de Ciências Biomédicas da Universidade de São Paulo, para obtenção do Título de Mestre em Ciências.

São Paulo

2012 
ADRIANA FRAGA COSTA SAMOS PARIS

\title{
O FATOR DE INIBIÇÃO DE MIGRAÇÃO DE MACRÓFAGOS (MIF) E A SOBREVIVÊNCIA DAS CÉLULAS DECIDUAIS. ESTUDO in vitro
}

\author{
Dissertação apresentada ao Programa de \\ Pós-Graduação em Biologia Celular e \\ Tecidual do Instituto de Ciências Biomédicas \\ da Universidade de São Paulo, para \\ obtenção do Título de Mestre em Ciências. \\ Área de concentração: \\ Biologia Celular e Tecidual \\ Orientadora: \\ Prof ${ }^{a}$. Drạ. Estela Bevilacqua \\ Versão original
}


DADOS DE CATALOGAÇÃO NA PUBLICAÇÃO (CIP)

Serviço de Biblioteca e Informação Biomédica do

Instituto de Ciências Biomédicas da Universidade de São Paulo

reprodução não autorizada pelo autor

Paris, Adriana Fraga Costa Samos.

O fator de inibição de migração de macrófagos (MIF) e a

sobrevivência das células deciduais . Estudo in vitro / Adriana Fraga

Costa Samos Paris. -- São Paulo, 2012.

Orientador: Prof. Dra. Estela Maris Andrade Forell Bevilacqua.

Dissertação (Mestrado) - Universidade de São Paulo. Instituto de Ciências Biomédicas. Departamento de Biologia Celular e do

Desenvolvimento. Área de concentração: Biologia Celular e Tecidual. Linha de pesquisa: Citofisiologia do Trofoblasto: estudo in vivo e in vitro dos aspectos celulares envolvidos na fisiologia do trofoblasto.

Versão do título para o inglês: The macrophage migration inhibitory factor (MIF) and decidual cells survival. In vitro study.

1. MIF 2. Sobrevivência celular 3. AKT 4. Decidua I. Bevilacqua, Profa. Dra. Estela Maris Andrade Forell II. Universidade de São Paulo. Instituto de Ciências Biomédicas. Programa de Pós-Graduação em Biologia celular e tecidual III. Título. 
Candidato(a):

Título da Dissertação:

Orientador(a):
Adriana Fraga Costa Samos Paris.

O fator de inibição de migração de macrófagos (MIF) e a sobrevivência das células deciduais. Estudo in vitro.

A Comissão Julgadora dos trabalhos de Defesa da Dissertação de Mestrado, em sessão pública realizada a considerou
( ) Aprovado(a)
( ) Reprovado(a)

Examinador(a): Assinatura:

Nome:

Instituição:

Examinador(a): Assinatura:

Nome:

Instituição:

Presidente: Assinatura:

Nome:

Instituição: 


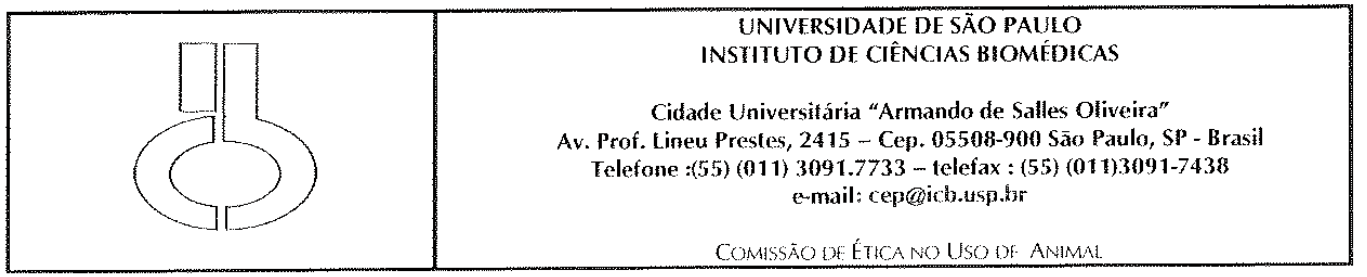

Decl. CEUA.058/10

\section{DECLARAÇ Ã O}

Em adendo ao Certificado 63/07/CEUA, com válidade até 31.08.2013 e por solicitaçāo da Profa. Dra. Estela Bevilacqua, responsável pela linha de Pesquisa, autorizo a inclusão da aluna Adriana Fraga Costa Samos Paris ao projeto de pesquisa "Expressão do fator de inibição de migração de macrófagos (MIF) durante o desenvolvimento placentário em camundongos", uma vez que se trata de utilização da mesma espécie animal e de métodos experimentais similares ao referido certificado.

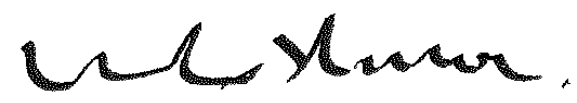

Prof. Dr. WOTHAN TAVARES DE LIMA

Coordenador

CEUA-ICB/USP 
Ao meu filho

Ao meu marído

À minha mãe

Dedico este trabalho 


\section{À professora Estela Bevilacqua}

Minha gratidão por me receber em seu laboratório, por me orientar nas pesquisas e também muitas vezes na vida por todos estes anos. Agradeço principalmente pela realização deste trabalho e por me formar cientificamente. Pela dedicação e compreensão para concluirmos a tempo, muito obrigada por tudo! 


\section{AGRADECIMENTOS}

À minha família, meu alicerce, minha fonte de força, entusiasmo e confiança, e familiares, agradeço pela compreensão da minha ausência durante a realização deste trabalho, pelo apoio, pelo incentivo. Cada um sabe a participação e importância na minha luta, nas minhas conquistas, na minha vida.

Ao Professor Dr. Douglas Zago, por despertar em mim o interesse pela Embriologia e Interação Materno-fetal na graduação, e por ter me encaminhado à Professora Estela no Trofo's Lab, onde realizei este trabalho.

À Professora Dra. Miriam Rubio Faria, pela grande colaboração neste trabalho: uma pequena parte do seu grande projeto. Também pela oportunidade de trabalhar e aprender muito com a brilhante equipe da Bioodontologia, área que me despertou interesse e que me fez direcionar minha opção profissional até chegar onde estou hoje.

À Professora Dra. Sonia Maria Gagioti, minha professora desde a graduação, coorientadora de TCC, companheira de trabalho e amiga, obrigada pelos ensinamentos e por toda a orientação em laboratório.

A Dra. Mara Sandra Hoshida, por tudo que me ensinou desde o início, pela amizade e pela confiança.

Ao Professor Dr. Sérgio Ferreira de Oliveira, pela colaboração neste estudo.

Ao Professor Dr. Decio dos Santos Pinto Junior, pela colaboração neste trabalho, além da Profa. Dra. Suzana Catanhede Orsini Machado de Sousa e Prof. Dr. Fabio Daumas Nunes também agradeço a permissão da execução de parte dos ensaios laboratoriais no Laboratório de Biologia Celular do Departamento de Estomatolgia FOUSP, junto a todos os professores da Disciplina de Patologia Bucal pelo apoio para a realização deste Mestrado: Marina Helena Cury Gallottini, Marília Trierveiler Martins, Andrea Mantesso e Karem Lopez Ortega.

Aos colegas da Patologia Bucal Elisa dos Santos, Juvani Lago Saturno, Zilı Natalina Ramos Alves, Neia Barbosa dos Santos e Nair Maria Pereira por todo apoio e convívio. 
À Rosangela Augusto de Oliveira, técnica do laboratório que me ensinou desde o estágio não somente cultivo celular, mas tudo sobre laboratório. Agradeço pelo eficiente auxílio nos ensaios deste trabalho e pelos conselhos que nos norteiam.

À Aline Rodrigues Lorenzon, pela ajuda na realização da eletroforese e transferência do Western Blotting, e pela amizade.

À amiga Karen Matias Prado, pelo auxílio no uso do software.

À secretária de Pós-Graduação do Departamento de Biologia Celular e do Desenvolvimento, Celiana Sandrelainy Marchiori por todas as orientações e atenção.

Ao Jose Braz Ferreira de Melo e todos os funcionários do Biotério, pelo cuidado com os animais utilizados neste trabalho.

Aos antigos colegas do Trofo's com quem aprendi ou compartilhei grande parte do que sei hoje e que me trazem boas memórias: Andréa Amarante, Bruna Galvez, Caroline Di Grado, Christie Andraus, Claudia Regina, Claudia Minazaki, Cristiane Murazawa, Eduardo Leanza, Fernanda Carini, Fernanda Magaldi, Luis Augusto, Mara Sandra, Mariana Poli, Sara Gomes e Tatiana Emanuela.

Aos atuais colegas do Trofo's pelos ocasionais convívios nos finais de tarde, noturnos e/ou de finais de semana: Alexandre Borbely, Aline Lorenzon, Aline Paixão, Camila Mendes, Carla Bandeira, Fernanda Carini, Karen Prado, Karollina Nascimento, Mariane Martucci, Paola, Rodrigo Weingril e Simone da Silva.

A todos os funcionários da biblioteca pelo atendimento e eficiência nos serviços prestados, principalmente a Monica da Silva Amaral pela presteza.

A todos que direta ou indiretamente contribuíram para a realização deste trabalho e que por acaso não estejam citados neste agradecimento. 
"O que você fizer será mais importante do que aquilo que conseguir. E como você se sentir por isso será ainda mais importante do que o que tiver feito." 


\section{RESUMO}

COSTA, A. F. O fator de inibição de migração de macrófagos (MIF) e a sobrevivência das células deciduais. Estudo in vitro. 2012. 82 f. Dissertação (Mestrado em Biologia Celular e Tecidual) - Instituto de Ciências Biomédicas, Universidade de São Paulo, São Paulo, 2012.

Estudos prévios em nosso laboratório mostraram na interface materno-fetal de camundongos, aos 10 dias de gestação, a expressão máxima do fator de inibição de migração de macrófagos (MIF) pelas células trofoblásticas e de seus receptores (CD44/CD74) pelas células deciduais, tornando estas células potenciais alvos da ação desta citocina. Dentre funções atribuídas a esta citocina, destacam-se ações pró-inflamatórias sobre a resposta imunológica e sobre processos de proliferação e sobrevivência celular. Neste contexto, este estudo tem como objetivo analisar uma possível participação de MIF na ativação de processos de sobrevivência celular mediados pela proteína quinase Akt, nas células deciduais de camundongo, in vitro. Utilizou-se cultivo primário de células deciduais que receberam MIF recombinante de camundongo (mrMIF) associado ou não a inibidores da via PI3K/AKT (LY294002 e Wortmannin). As culturas foram analisadas por meio de reações imunohistoquímicas, Western blot e ensaios de morte celular. Assim como in vivo, o complexo receptor de MIF, CD74/CD44 foi imunolocalizado nas células deciduais cultivadas. A adição de MIF exógeno reduziu os níveis de apoptose. MIF também interferiu no processo de sobrevivência das células deciduais in vitro diminuindo as taxas de morte por apoptose quando desafiadas com peróxido de hidrogênio. Além disto, as células tratadas com mrMIF apresentaram maior expressão de pAKT e pMDM2. Dados da literatura mostram que a via AKT é responsável por ativar mecanismos de sobrevivência celular e sua ativação por MIF nas células deciduais pode indicar um papel para esta citocina na homeostase decidual, garantindo a integridade da barreira materno-fetal e, desta forma, a manutenção desta interface imprescindível para o sucesso da gestação.

Palavras-chave: MIF. Sobrevivência celular. AKT. Decídua. 


\begin{abstract}
COSTA, A. F. The macrophage mig2ation inhibitory factor (MIF) and decidual cells survival. In vitro study. 2012. 82 p. Masters thesis (Sciences in Tissue and Cell Biology) - Instituto de Ciências Biomédicas, Universidade de São Paulo, São Paulo, 2012.

Previous studies from our laboratory showed that the maternal-fetal interface in mouse at gestation day 10 exhibits high levels of macrophage inhibiting migration factor (MIF) expressed by trophoblast cells and its receptors (CD44/CD74) by decidual cells, making these cells potential targets for this cytokine action. Among the roles attributed to this cytokine, it can be highlighted the pro inflammatory actions on the immune response and on proliferation and cellular survival processes. In this context, this study aim to analyze the possible role of MIF in the activation of survival mechanisms mediated by the protein kinase Akt in mouse decidual cells in vitro. We have used primary culture of decidual cells receiving recombinant mouse MIF (mrMIF) with or without the PI3K/AKT pathway inhibitor (LY294002 and Wortmannin). Cultures were analyzed by immunohistochemical reactions, Western blotting and cell death analysis. As in vivo, the MIF receptor complex, CD74/CD44 was immunolocalized in the cultured decidual cells. The addition of exogenous MIF reduced the apoptotic rates in decidual cells. MIF also interfered in the process of survival of decidual cells in vitro by decreasing rates of cell death by apoptosis when challenged with hydrogen peroxide. In addition, cells treated with $\mathrm{mrMIF}$ have higher expression of pAKT and $\mathrm{pMDM}_{2}$. Recent studies show that AKT pathway is responsible for cell survival. In this context, AKT activation by MIF in decidual cells may indicate a role for this cytokine in decidual homeostasis by ensuring the integrity of the maternal-fetal barrier and thereby, maintaining this essential interface and successful pregnancy.
\end{abstract}

Keywords: MIF. Cell survival. AKT. Decidua 


\section{LISTA DE FIGURAS}

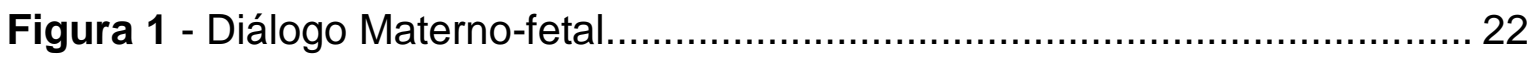

Figura 2 - Vias possíveis de sinalização de MIF.............................................25

Figura 3 - Esquema do sítio de implantação................................................. 35

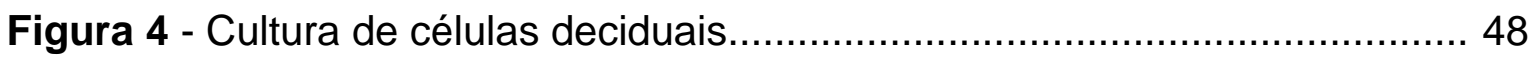

Figura 5 - Viabilidade das células deciduais.................................................. 49

Figura 6 - Caracterização das células deciduais.............................................. 51

Figura 7 - Expressão de MIF e seus receptores pelas células deciduais

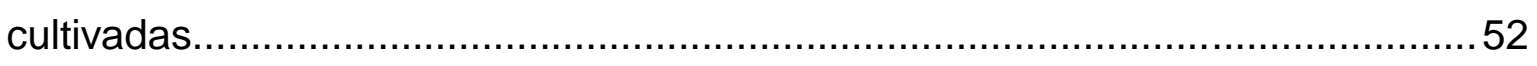

Figura 8 - Determinação da concentração ideal de mrMIF..................................53

Figura 9 - Sobrevivência das células deciduais após tratamento com $\mathrm{H}_{2} \mathrm{O}_{2} \ldots \ldots . . .55$

Figura 10 - Imunolocalização de AKT e pAKT em células deciduais................... 56

Figura 11 - Imunolocalização de $\mathrm{MDM}_{2}$ e $\mathrm{pMDM}_{2}$ em células deciduais..............57

Figura 12 - Quantificação de AKT, pAKT, $\mathrm{MDM}_{2}$ e $\mathrm{pMDM}_{2}$ em células deciduais. 


\section{LISTA DE QUADROS}

Quadro 1 - Anticorpos primários e secundários utilizados nas reações de

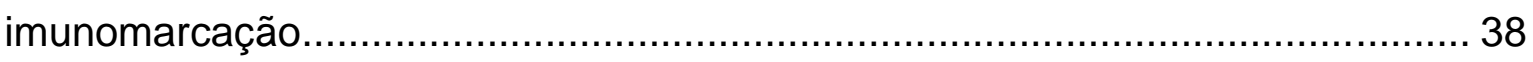

Quadro 2 - Anticorpos primários e secundários utilizados nas reações de Western Blotting. 


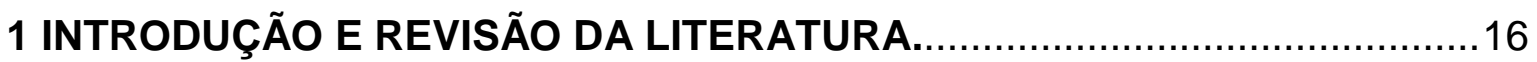

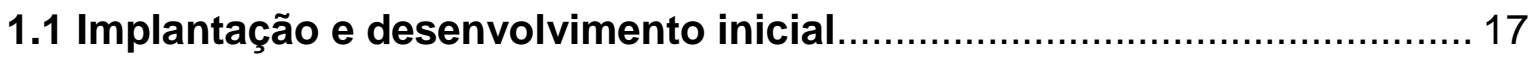

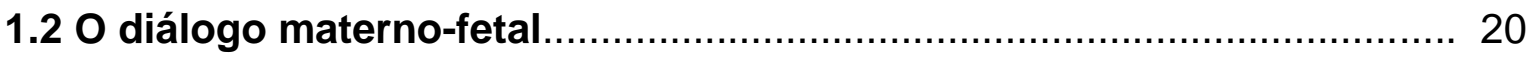

1.2.1 Fator de Inibição de Migração de Macrófagos (MIF)..................................22

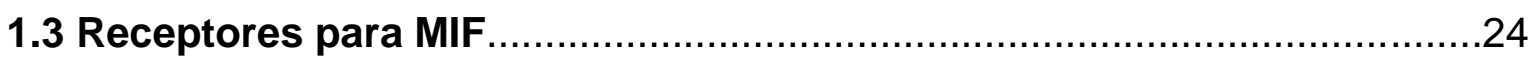

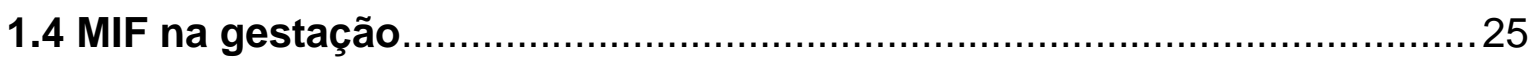

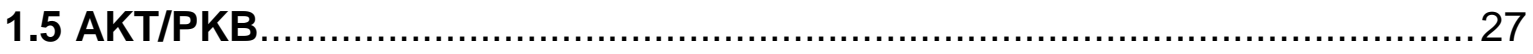

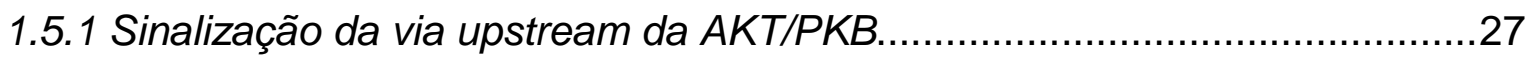

1.5.2 Sinalização da via downstream da AKT/PKB....................................... 28

1.6 MIF promove a sobrevivência celular ativando PI3K/AKT ........................28

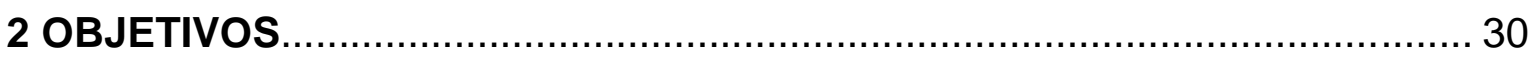

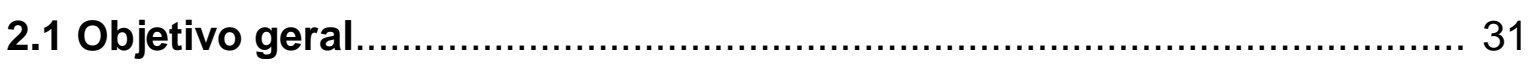

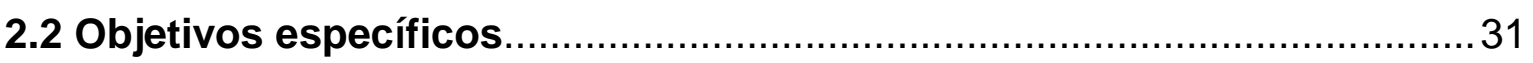

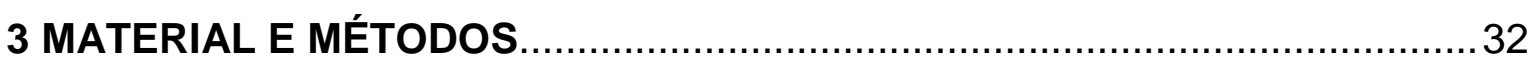

3.1 Reagentes e suas procedências....................................................... 33

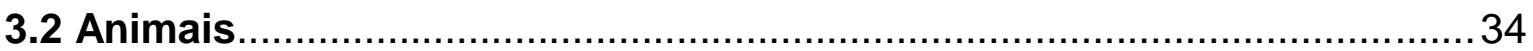

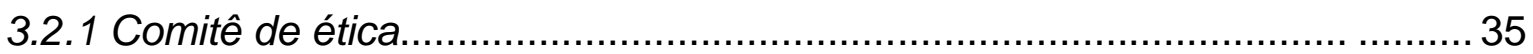

3.3 Obtenção das células deciduais e manutenção in vitro............................ 35

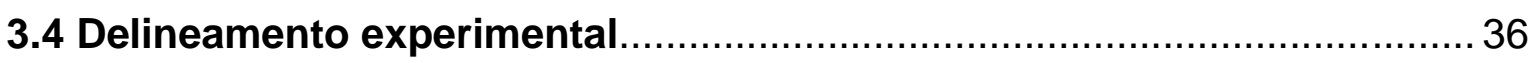

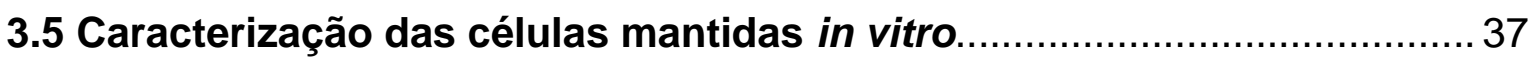

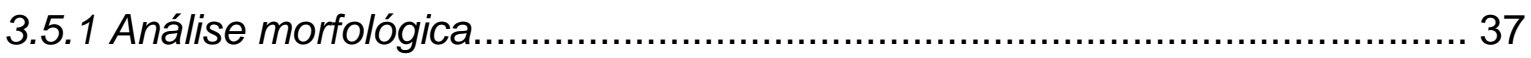

3.5.2 Imunolocalização de antígenos utilizados como marcadores das células

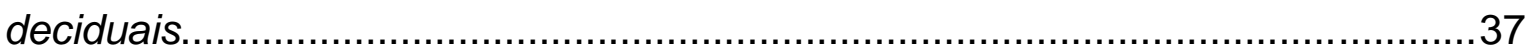

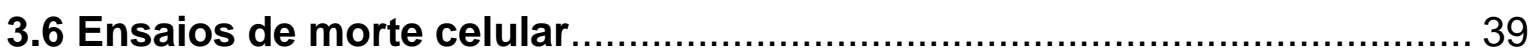

3.6.1 Reação de TUNEL para identificação de células em processo de morte por apoptose...

3.6.2 Coloração com albumina-FITC para identificação de células em processo de

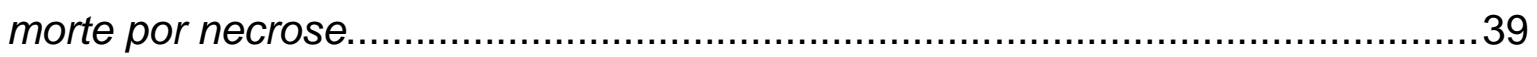

3.7 Viabilidade das células deciduais................................................... 40

3.7.1 Viabilidade em função do tempo de cultivo........................................ 40

3.7.2 Imunolocalização de Ki67................................................................ 40 
3.7.3 MTS (3-(4,5-dimetiltiazol-2-yl)-5-(3-carboxymetoxifenil)-2-(4-sulfofenil)-2H-

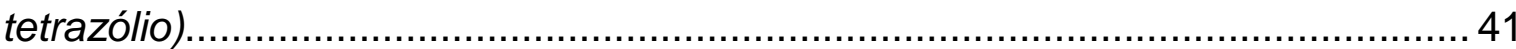

3.8 Expressão de MIF e seus receptores pelas células deciduais in vitro.....41

3.9 Ensaios de sobrevivência celular mediada pelo MIF ............................. 42

3.10 Expressão proteica nas células deciduais tratadas com mrMIF........... 43

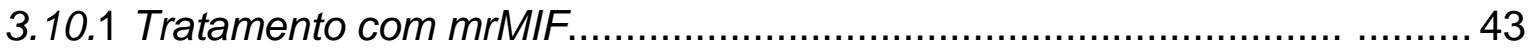

3.10.2 Análise por imunofluorescência............................................................ 43

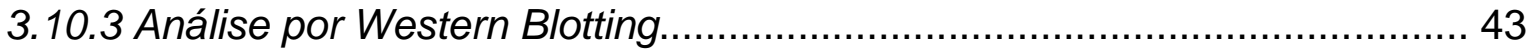

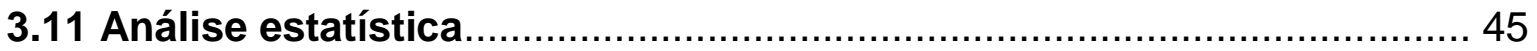

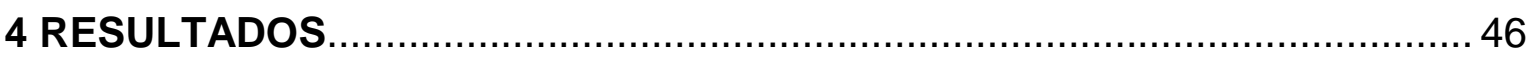

4.1 Caracterização das células deciduais............................................ 47

4.2 Expressão de MIF e seus receptores pelas células deciduais in

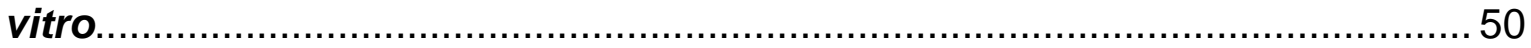

4.3 Determinação da concentração ideal de mrMIF................................. 50

4.4 Sobrevivência das células deciduais após tratamento com $\mathrm{H}_{2} \mathrm{O}_{2}$ na presença de MIF

4.5 Imunolocalização e expressão das proteínas AKT e $M_{2} M_{2}$ nas formas fosforilada e não fosforilada.................................................................. 54

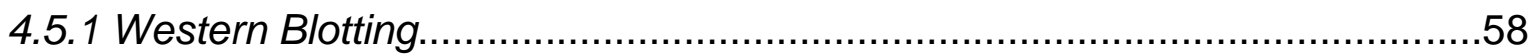

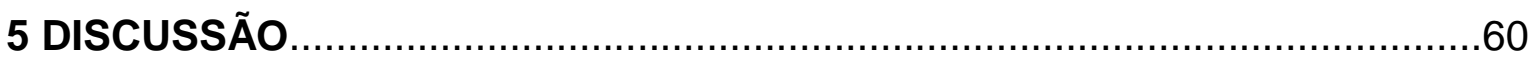

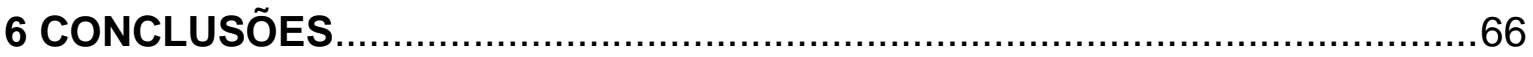

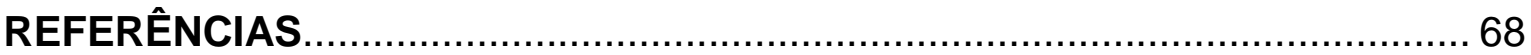


1 INTRODUÇÃO E REVISÃO DA LITERATURA 


\subsection{Implantação e desenvolvimento inicial}

Em mamíferos, para que uma gestação tenha sucesso adaptações funcionais e anatômicas são necessárias no organismo materno, na interface materno-fetal e na placenta. Estes mecanismos guardam semelhanças entre si nas diferentes espécies, ao mesmo tempo em que seguem rumos próprios dentro de cada uma delas. Em primatas e roedores, por exemplo, encontramos uma condição ímpar caracterizada pela formação de uma placenta do tipo hemocorial em que células embrionárias pertencentes à placenta estabelecem um íntimo contato com o sangue materno (MOSSMAN, 1937; WELSH; ENDERS, 1987). Desta forma, a barreira placentária que em algumas espécies é formada por inúmeros tecidos maternos e fetais, nestas espécies fica reduzida a uma estreita e altamente especializada membrana fetal, o cório (CROSS et al., 2002).

Independente da espécie e do caminho evolutivo seguido, entretanto, a gestação depende primordialmente de complexos e multifatoriais mecanismos de interação, comunicação e tolerância. Estes eventos iniciam-se precocemente e têm sido estudados durante o processo de implantação embrionária e placentação.

Particularmente em roedores, a implantação embrionária inicia-se ao redor do quinto dia de gestação (FINN, 1971; RESTAL; BINDON, 1971). O embrião na fase de blastocisto na cavidade uterina adere ao epitélio uterino e, através de diferentes mecanismos moleculares, invade o endométrio até se inserir completamente no estroma uterino (BEVILACQUA; ABRAHAMSOHN, 1989; TACHI S; TACHI C; LINDNER, 1970).

Ao mesmo tempo em que o embrião adentra o endométrio, este sofre alterações importantes para permitir o alojamento e desenvolvimento embrionário. Este processo denomina-se reação decidual, envolve modificações morfológicas dos fibroblastos e de outros componentes da mucosa uterina (ABRAHAMSOHN, 1983; ABRAHAMSOHN; ZORN, 1993; ENDERS; SCHLAFKE, 1978; FINN, 1971; KLEINFELD; MORROW; DEFEO, 1976; MOSSMAN, 1937) e mudanças nos padrões funcionais do endométrio, dentre as quais se destacam: receptividade ao concepto, produção de hormônios e moléculas reguladoras, tolerância imunológica, remodelação vascular e atividade angiogênica (CROSS et al., 2002; PLAISIER, 2011). 
Durante a formação da decídua, fibroblastos locais sofrem um processo de rediferenciação, assumem forma poligonal, acumulam glicogênio e lipídeos, tornamse volumosas e justapostas, estabelecem junções especializadas entre células vizinhas (BEVILACQUA; ABRAHAMSOHN, 1989; FINN, 1971), alteram a expressão de proteínas e de componentes da matriz extracelular (ABRAHAMSOHN; ZORN, 1993; ALBERTO-RINCON; ZORN; ABRAHAMSOHN, 1989; BIJOVSKY; ZORN; ABRAHAMSOHN, 1992; OLIVEIRA et al., 1995; ZORN; BEVILACQUA; ABRAHAMSOHN, 1986, ZORN et al., 1989) e acumulam filamentos intermediários de desmina (CAN; TEKELIOGLU; BALTACI, 1995; GLASSER; JULIAN, 1986; GLASSER et al., 1987; ZORN; DE OLIVEIRA; ABRAHAMSOHN, 1990). Essas células constituem desta forma, uma população celular de características próprias, associadas à gestação e, principalmente, voltadas para a interação com o organismo embrionário.

$\mathrm{Na}$ medida em que o processo de implantação embrionária prossegue 0 embrião de roedor ultrapassa a camada epitelial uterina e gradualmente invade o estroma endometrial (AMOROSO, 1955; APLIN, 2006; CROY, 2003; FERRO; BEVILACQUA, 1994). Este processo é mediado pelas células de revestimento do blastocisto que se diferenciam ao contato com o endométrio para formar células poliplóides, gigantes, fagocíticas e altamente invasivas (BEVILACQUA; ABRAHAMSOHN, 1989; TACHI S; TACHI C; LINDNER, 1970). Através de um ativo processo invasivo estas células alcançam os vasos sanguíneos subepiteliais, substituindo células endoteliais e passando a fazer contato direto com o sangue materno em toda a periferia embrionária (AMOROSO, 1955; APLIN, 2006; BEVILACQUA; ABRAHAMSOHN, 1989; CROY, 2003). Esta condição permite as trocas moleculares entre os organismos materno e embrionário, mesmo nas fases mais precoces da gestação e antes que a placenta esteja plenamente formada (ENTRICAN, 2002; ROBERTSON, 2007).

Além de ancorar o embrião no endométrio a implantação embrionária caracteriza uma fase de intenso diálogo materno-fetal. A interface materno-fetal formada pelas células trofoblásticas gigantes que circundam o embrião, e a decídua com todos seus tipos celulares peculiares e células do sistema imunológico e de defesa orgânica, passam a interagir física e funcionalmente (AMARANTE-PAFFARO et al., 2004; GUILBERT; ROBERTSON; WEGMANN, 1993; LIN et al., 1993; PAVIA, 1983; RUTANEN, 1993). 
Dekel et al. (2010) mostraram que um ambiente inflamatório é favorável à implantação. Os autores estudaram mulheres com baixa receptividade no endométrio e altos índices de aborto espontâneo, mostrando aumento de receptividade uterina em mulheres em que uma reação inflamatória indiretamente foi induzida pela obtenção de biópsias endometriais poucos dias antes do procedimento de fertilização in vitro, reação inflamatória com um aumento na expressão de moléculas que melhoram esta receptividade.

Após o oitavo dia de gestação com a gastrulação, o mesenquima alantoideano alcança o trofoblasto polar denominado de cone ectoplacentário, e com as células mais basais desta estrutura forma 0 cório. $O$ cório e as células trofoblásticas mais periféricas do cone ectoplacentário formarão a placenta (CROSS et al., 2002).

A partir da placa coriônica será formada a região do labirinto placentário nos dias subseqüentes. A região labiríntica é responsável pelas trocas metabólicas e gasosas entre sangue materno e fetal e, é formada por três camadas de células trofoblásticas sendo duas sinciciais e uma de células individualizadas (ANSONCARTWRIGHT et al., 2000; CROSS et al., 2002). A superfície externa da camada de células trofoblásticas é banhada por sangue materno enquanto que a face interna repousa sobre o mesenquima vascularizado.

A região mais periférica do cone ectoplacentário, formado por células trofoblásticas gigantes e não gigantes é designada de zona juncional (CROSS et al., 2002). As células gigantes estabelecem contato com as células deciduais, com os vasos uterinos e entre outras células trofoblásticas através de seus prolongamentos, formando uma malha celular por onde percola o sangue materno. As células trofoblásticas não gigantes se diferenciam em células que acumulam glicogênio e em células secretoras de hormônios e moléculas reguladoras (ADAMSON et al., 2002; CROSS, 2005).

Assim durante toda a gestação, seja na fase de implantação embrionária seja na fase de formação e atividade placentária, uma relação íntima entre os tecidos materno e fetal se desenvolve associada à expressão de diferentes moléculas sinalizadoras/reguladoras e seus respectivos receptores formando uma rede de comunicação imprescindível para o crescimento, diferenciação e manutenção da tríade útero-embrio-placenta. 


\subsection{0 diálogo materno-fetal}

A sobrevivência de um feto semialogênico no organismo materno tem despertado a atenção da Ciência por muitos anos. Os mecanismos bioquímicos e moleculares que permitem este aparente paradoxo imunológico ainda não estão completamente elucidados. No entanto, atualmente um papel chave tem sido atribuído à secreção de uma ampla variedade de moléculas solúveis de ação autócrina / parácrina, incluindo fatores de crescimento, citocinas e hormônios. Estas substâncias produzidas na interface materno-fetal principalmente por células trofoblásticas, células deciduais e outras células presentes na decídua como células $\mathrm{T}$, principalmente do tipo uNK (natural killer uterinas), células dendríticas e macrófagos, atuam como sinais de comunicação (Figura 1). Esta troca recíproca de moléculas é a base de uma relação interativa entre embrião e mãe e certamente contribui para os mecanismos de tolerância fetal ou seja, esta condição favorece a sobrevivência e crescimento do trofoblasto ao invés de rejeitá-lo.

Este diálogo materno-fetal é precoce na gestação, iniciando-se pela secreção trofoblástica de gonadotrofina coriônica em humanos e pelo hormônio lactogênio placentário em murinos, induzindo um ambiente favorável à implantação e desenvolvimento embrionário no organismo materno. Outras moléculas se seguem com o progresso da gestação, produzidas tanto pelo organismo fetal quanto pelo materno. Em humanos e roedores, a invasão trofoblástica persiste além da ancoragem do embrião no útero, tendo como consequência o contato físico e funcional de células trofoblásticas e uma grande variedade de células maternas, representadas por células glandulares, deciduais, estromais, endoteliais e outras tantas imunologicamente competentes (Figura 1). Interação entre estes componentes da interface materno-fetal mediada por moléculas de regulação tem sido amplamente descrita na literatura científica atual (CHAMPION et al., 2012; COHEN; BISCHOF, 2007; FARIA et al., 2010; LASH et al., 2005; LASH; ROBSON; BULMER; 2010; LIN et al., 1993; VASSILIADIS et al., 1998; ZHOU et al., 2008). Neste contexto, o diálogo materno fetal depende da ativa contribuição de ambos os organismos, seja para emitir uma mensagem ou para compreendê-la.

Dentre as moléculas sinalizadoras da gestação particular ênfase tem sido dada a citocinas. Estudos têm mostrado que durante a fase de implantação embrionária há um aumento de citocinas inflamatórias e dentre elas por exemplo o 
LIF (fator inibidor de leucemia), que produzido pelo endométrio age sobre o embrião e é essencial para a implantação e aparentemente também para a manutenção da gestação, uma vez que mulheres com abortos recorrentes apresentam sua expressão diminuída (GREMLICH et al., 2012; PICCINNI; MAGGI; ROMAGNANI, 2000). Outro exemplo é o SDF-1 (fator derivado de células estromais-1), que secretadas pelas células trofoblásticas agem sobre as células deciduais (ZHOU et al., 2008).

Muitas outras citocinas já foram relatadas como imprescindíveis para o sucesso da gestação e já foram identificadas na interface materno-fetal em condições normais, interleucina-6 (IL-6) (CHAMPION et al., 2012), CCL16 (citocina motivo C-C tipo 16) (MÄKIKALLIO et al., 2012), interleucina-1 (IL-1), IL2, IL3, IL4, IL5, IL8, IL12p70 e IL13 (LASH; ROBSON; BULMER, 2010; LIN et al., 1993; VASSILIADIS et al., 1998). Outras foram também descritas mas seu papel não totalmente elucidado como por exemplo o fator de inibição de migração de macrófagos (MIF) (ARCURI et al., 2006; FARIA et al., 2010) e receptores de citocinas como CXCR4 (receptor de citocina motivo C-X-C tipo 4) (YANG et al., 2006). É importante ressaltar que uma alteração na expressão destas citocinas entretanto, pode afetar o sucesso gestacional (DAHL; HVIID, 2012; GREMLICH et al., 2012; LASH; ROBSON; BULMER, 2010; MATTHIESEN; KALKUNTE; SHARMA, 2012; ORESHKOVA; DIMITROV; MOURDJEVA, 2012; PERRICONE C; DE CAROLIS; PERRICONE R, 2012; RAGHUPATHY, 1997; RODE et al., 2012; XIE et al., 2010). A sinalização materno fetal também pode ocorrer através de outras moléculas como por exemplo fatores de crescimento como a angiopoietina (Ang) 1, fator de crescimento endotelial vascular (VEGF), angiogenina (Ang) 2, fator de crescimento fibroblástico (FGF) e o fator de crescimento de queratinócitos (KGF), na medida em que estes ligantes e seus receptores específicos agem como fatores de comunicação entre os organismos materno e fetal.

Mecanismos epigenéticos de regulação gênica também ocorrem na placenta e podem participar da regulação do diálogo materno fetal. A expressão de determinados genes respondendo tanto a sinais fetais, quanto a sinais maternos pode ser ativada para que o desenvolvimento do embrião tenha sucesso. Neste contexto, foi já descrito mecanismo de regulação de genes que controlam a quantidade de nutrientes que atravessam a barreira placentária manipulando, desta forma, a fisiologia materna, por vezes contra sua própria homeostase (SANDOVICI 
et al., 2012) ou ainda, genes que codificam citocinas que podem limitar o tráfego de células T efetoras e influenciar o mecanismo de tolerância materno-fetal (NANCY et al., 2012).

Figura 1 - Diálogo materno-fetal

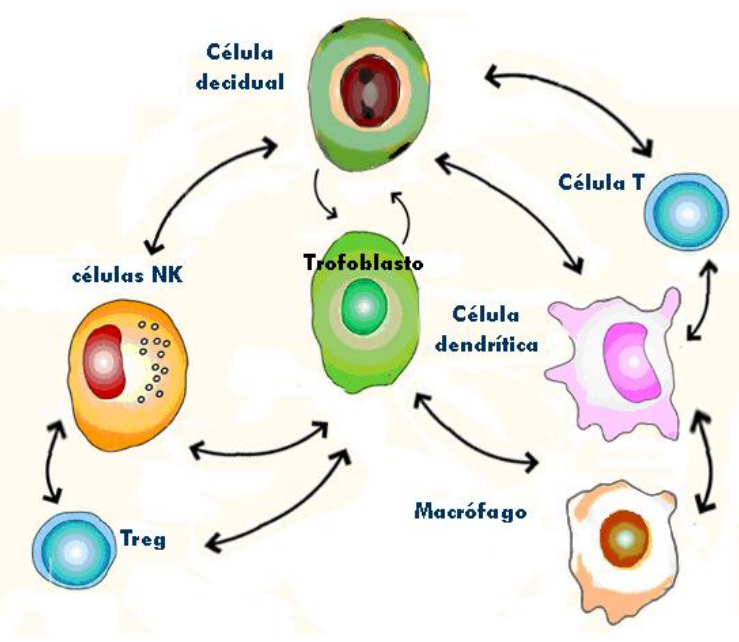

Células da interface materno-fetal. Após a implantação embrionária células trofoblásticas entram em contato físico e funcional com diferentes tipos celulares maternos presentes na decídua. Moléculas produzidas por cada uma destas células ao interagirem entre si estabelecem vias de sinalização e um intenso e imprescindível diálogo que leva ao sucesso da gestação.

\subsubsection{Fator de Inibição de Migração de Macrófagos (MIF)}

A citocina pró-inflamatória MIF (Fator de Inibição de Migração de Macrófagos) é um polipeptídio de 114 resíduos com peso molecular de 12,5 kDa e foi descrita pela primeira vez em 1966 por Bloom e Bennett. Sua expressão constitutiva gênica e proteica foi já mostrada em diferentes órgãos, entre os quais cérebro, hipófise (BERNHAGEN et al., 1993), rins (LAN, 2008), pulmões (DONNELLY et al., 1997), placenta (IETTA et al., 2007), fígado, baço, adrenal e pele (CALANDRA; ROGER, 2003); sendo produzida por diversos tipos celulares como linfócitos, macrófagos, neutrófilos, eosinófilos, monócitos (BAUGH; BUCALA, 2002), fibroblastos (HONDA et al., 2008), trofoblasto (FARIA et al., 2010; PAULESU et al., 2005, 2010) e células endoteliais (NISHIHIRA; KOYAMA; MIZUE, 1998), além de estar presente nas membranas fetais (ZICARI et al., 2006), soro materno (IETTA et al., 2002; TODROS 
et al., 2005), fluído amniótico (IETTA et al., 2002), endométrio e decídua (ARCURI et al., 2001). Sua secreção é estimulada por estresse e inflamação, resultando em uma liberação rápida do produto protéico armazenado no citoplasma (CALANDRA et al., 1994; CALANDRA; ROGER, 2003).

O MIF difere de outras citocinas por apresentar inúmeras propriedades: i. é um regulador crítico de funções celulares como proliferação e sobrevivência (MITCHELL et al., 2002) e supressor da ativação de apoptose (HUDSON et al., 1999), ii. induz ativação de outras citocinas inflamatórias tais como o fator de necrose tumoral alfa (TNF $\alpha$ ), interferon gama (IFN- $\gamma$ ) (CALANDRA et al., 1994) e óxido nítrico (BOZZA et al., 1999), iii. regula Toll like receptor 4 (TLR4) (ROGER et al., 2001) e, iv. é antagonista fisiológico de glicocorticóides (FLASTER et al., 2007). MIF é um mediador crítico em diversas doenças tais como o choque séptico, artrite reumatóide, doenças inflamatórias de pulmão e câncer (CALANDRA et al., 1995; LUE et al., 2002, 2006, 2007; VIGANO et al., 2007), e parasitoses (CARVALHO et al., 2010; DE OLIVEIRA GOMES et al., 2011; FERRO et al., 2008; FRANCO et al., 2011). Além da alta homologia entre os MIFs de mamíferos ( 90\%), a presença deste fator também ocorre em aves, peixes, parasitas, plantas e cianobactérias, o que indica que esta molécula deve desempenhar funções biológicas importantes (GUILIANO et al., 2002; JAWORSKI et al., 2001; PASTRANA et al., 1998; SATO et al., 2003; WISTOW et al., 1993).

Particularmente em macrófagos e células tumorais, o MIF regula funçõeschave como crescimento, migração, supressão de apoptose, sobrevivência e inativação de inibidores do ciclo celular (GORE et al., 2008; HUDSON et al., 1999; LUE et al., 2007; MITCHELL et al., 2002; SONG; OUYANG; BAO, 2005). Nos tecidos em geral está principalmente envolvido com a inibição de apoptose e indução de síntese protéica sendo considerada uma proteína fundamental para a ativação de vias de sinalização celular que levam ao crescimento tecidual (GORE et al., 2008; HUDSON et al., 1999; MITCHELL et al., 2002). Evidências sugerem que MIF está também envolvido na fase inicial da tumorigênese e promove angiogênese, enquanto que seu papel em estágios tardios é desconhecido (GORE et al., 2008; LUE et al., 2002; MITCHELL et al., 2004). 


\subsection{Receptores para MIF}

A atividade biológica de MIF está predominantemente associada a sua ligação ao complexo receptor/coreceptor: CD74 e CD44, o que pode resultar na ativação de diferentes vias de sinalização. O receptor CD74 foi descrito inicialmente como um receptor de superfície celular para MIF (LENG et al., 2003). Alguns anos depois, CD44 foi descrito como parte integrante de um complexo receptor associado a CD74 (MEYER-SIEGLER; LEIFHEIT; VERA, 2004; SHI et al., 2006), sendo o domínio intracitoplasmático de CD74 imprescindível para a transdução do sinal de MIF (SHI et al., 2006). MIF é capaz de se ligar ao receptor de superfície celular CD74, mas não ativa vias de sinalização se CD44 não estiver presente ou ativo (GORE et al., 2008; SHI et al., 2006). A ligação de MIF ao CD74 leva à adição de sulfato de condroitina a sua estrutura (CD74-CS), que age como uma proteína acessória na associação CD74 e CD44 (BESWICK; REYES, 2009; NAUJOKAS et al., 1993), o que resulta na ativação de vias de sinalização dependente de Srckinase, PI3K-AKT/PKB (fosfatidilinositol-3-quinase/proteína kinase B) (GORE et al., 2008; SHI et al., 2006). Ainda, estudos realizados por Shi et al. (2006) indicam que a inibição de apoptose dependente de p53 conferida por MIF é dependente de CD74 e CD44 (GORE et al., 2008; LUE et al., 2007; STARLESTS et al., 2006).

MIF pode ainda se ligar funcionalmente a receptores de quimiocina CXCR2 e CXCR4 onde participa do controle para o recrutamento inflamatório de leucócitos (BERNHAGEN et al., 2007). Além dos receptores CD44-CD74, CXCR2 e CXCR4, para iniciar ativação de vias de sinalização para MIF, há também sua captação por endocitose (Figura 2) (BERNDT et al., 2008). Quando endocitado junto a CD74 é capaz de ativar a via de sinalização ERK (extracellular signal-regulated kinases) (XIE et al., 2011). Estas quinases são membros da família das quinases ativadoras de mitógenos [mitogen activated protein kinase, MAPK] capazes de induzir processos fisiológicos como proliferação e diferenciação. 
Figura 2 - Vias possíveis de sinalização de MIF

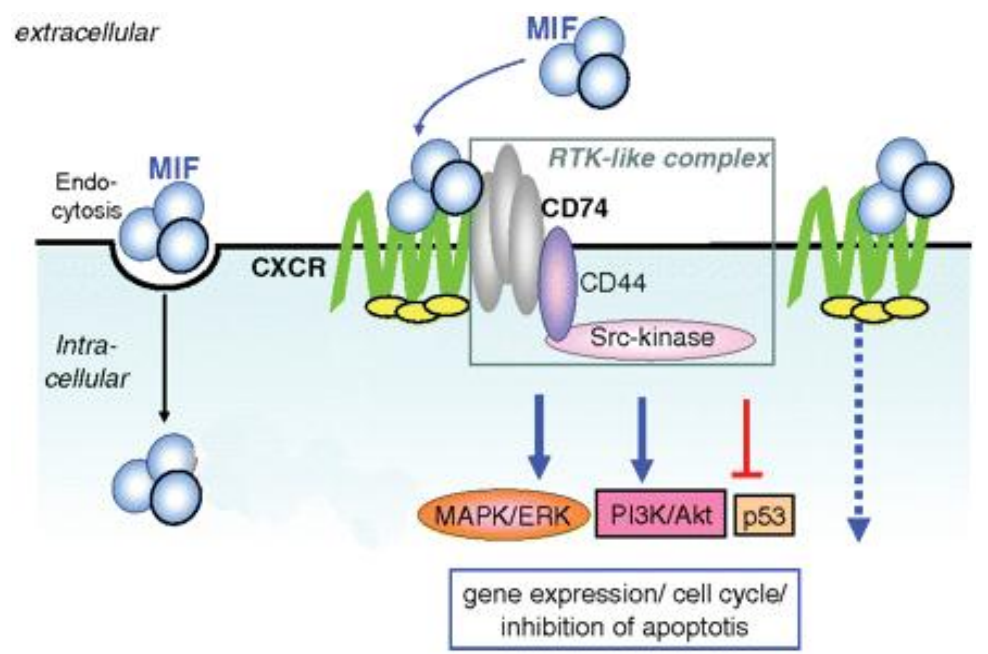

MIF pode agir ligando-se a complexo-receptores CD74/CD44, CXCR ou por endocitose, ativando as vias de sinalização MAPK/ERK ou PI3K/AKT.

Fonte: Adaptado de Zernecke, 2008

\subsection{MIF na gestação}

MIF tem sido estudado por diferentes grupos de estudos em diferentes espécies, sua expressão gênica e proteica ao longo da gestação na interface materno-fetal tem sido mostrada em murinos (FARIA et al., 2010; SUZUKI et al., 1996a; SUZUKI; KANAGAWA; NISHIHIRA, 1996b) e em humanos (ARCURI et al., 1999, 2001, 2007; IETTA et al., 2007; VIGANO et al., 2007), assim como seu complexo receptor CD74/CD44 em murinos (MARTUCCI, 2010) e CD 74 em humanos (XIE et al., 2010). Estes achados sugerem um papel regulatório no processo de implantação embrionária, desenvolvimento placentário e manutenção gestacional (IETTA et al., 2007; PAULESU et al., 2005). Em humanos, Arcuri et al. (2007) sugeriram que a presença de MIF na decídua a termo pode estar relacionada à regulação da migração de macrófagos na interface materno-fetal e a uma ação sobre as células natural killer uterinas (UNK), contribuindo para o privilégio imunológico da interface materno-fetal.

Sua expressão foi descrita em órgãos do sistema reprodutivo feminino em humanos ao longo do ciclo menstrual e estral e em diferentes fases da gestação (ARCURI et al., 2001; PAULESU et al., 2005; SUZUKI et al., 1996a; SUZUKI; KANAGAWA; NISHIHIRA, 1996b). Foram encontradas diferenças quanto à expressão de MIF ao longo do ciclo menstrual que poderiam direta ou indiretamente afetar a proliferação celular, angiogênese e remodelação tissular (KATS et al., 
2005). A expressão de MIF na gestação a termo sugere que MIF contribui para eventos inflamatórios que conduzem ao parto (IETTA et al., 2002). MIF é altamente expresso nas fases de implantação e peri-implantação em humanos podendo desempenhar um papel crítico neste evento e no desenvolvimento embrionário inicial (ARCURI et al., 1999). Particularmente no epitélio glandular e estroma endometrial sua expressão sugere que MIF é parte integrante da rede de citocinas da gestação (ARCURI et al., 2001).

Ainda em humanos, Cardaropoli et al. (2012) indicaram que MIF está envolvido na patogênese da pré-eclâmpsia e mostraram que diferentes tecidos placentários (membranas fetais patológicas, células endoteliais, citotrofoblasto, sinciciotrofoblasto, camada epitelial, mesênquima e decídua) contribuem para a produção de MIF em gestações com esta patologia com ou sem restrição de crescimento fetal. Este estudo corroborou o trabalho de Todros et al. (2005), que mostrou aumento dos níveis séricos maternos de MIF nas gestações complicadas por pré-eclâmpsia, enfatizando o caráter inflamatório desta enfermidade. A expressão de MIF também aumenta na placenta em condições de hipóxia in vitro, o que pode estar relacionado ao controle do crescimento do trofoblasto (IETTA et al., 2007).

Em murinos, Suzuki et al. (1996a) identificaram MIF no fluído amniótico em concentração diferente da produzida pelo organismo materno, sugerindo uma função autócrina no desenvolvimento embrionário.

Resultados prévios obtidos por nosso grupo mostraram que a citocina próinflamatória MIF também é expressa ao longo da gestação em camundongos principalmente na face fetal da placenta e seu complexo receptor, CD74/CD44, principalmente na decídua (FARIA et al., 2010; MARTUCCI, 2010). A expressão gênica e proteica de MIF e seus receptores é alta na interface materno-fetal no dia 7,5 de gestação, atingindo valores máximos no dia 10,5 de gestação (dg). Neste mesmo período, análises imunohistoquímicas localizaram os receptores de MIF em leucócitos e células deciduais, tornando estas células potenciais alvos da ação desta citocina. 


\subsection{AKT/PKB}

O gene de AKT foi descoberto inicialmente em um retrovírus com potencial oncogênico em camundongos, porém as isoformas só foram identificadas em 1991 (BELLACOSA et al., 1991; COFFER; WOODGETT, 1991)

$A K T$, também chamada de PKB, é uma proteína quinase serina/treonina de $60 \mathrm{kDa}$ importante por modular a função de diversos substratos envolvidos em processos biológicos tais como: síntese de proteínas, crescimento, proliferação, angiogênese, metabolismo de glicose e sobrevivência (MANNING; CANTLEY, 2007). O gene apresenta variantes de transcritos por splicing alternativo, denominados AKT1, AKT2 e AKT3, sendo a AKT1 a isoforma mais encontrada e envolvida em processos vitais como a sobrevivência. AKT2 é uma molécula de sinalização na via da insulina, e AKT3, a menos conhecida, é encontrada predominantemente no cérebro. A arquitetura de AKT é bem conservada entre as espécies e apresenta três domínios funcionais: $\mathrm{N}$-terminal PH (pleckstrin homology), central quinase e um domínio regulatório carboxi-terminal hidrofóbico (HMhydrophobic motif) (FAYARD, 2005; KUMAR; MADISON, 2005; YANG et al., 2002).

Já se sabe que camundongos knockout para AKT/PKB apresentam desenvolvimento anormal de pelos, ossos e músculos, menor desenvolvimento cerebral, maior índice de morte pós-natal, restrição de crescimento e defeitos congênitos, além de alterações na formação placentária (FAYARD et al., 2005; YANG et al., 2004).

\subsubsection{Sinalização da via montante (upstream) da AKT/PKB}

A ativação de AKT inicia-se pela autofosforilação de receptores tirosina quinase, por ligação de fatores de crescimento (AUGER et al., 1989) ou citocinas, por estimulação de proteína $G$ acoplada ou por ativação de sinalização via integrinas. Todos levam à ativação de fosfatidilinositol-3-quinase (PI3K) que fosforila fosfatidilinositol P2 (PIP2) convertendo-o em fosfatidilinositol P3 (PIP3) (fosfolipídeos de membrana plasmática), que leva à translocação de AKT para a membrana, manobra necessária para sua interação com PIP3 (BRAZIL et al., 2001; FAYARD et al., 2005). AKT pode ser fosforilada pela quinase piruvato desidrogenase (PDK) 1 na treonina 308 ou por PDK2 na serina 473 (ALESSI et al., 1997; MANNING; 
CANTLEY, 2007; VIVANCO; SAWYERS, 2002) e para que sua ativação ocorra é necessária a fosforilação desses dois sítios (SONG; OUYANG; BAO, 2005).

A ativação de PI3K pode ser bloqueada por intermédio das substâncias wortmannin (ARCARO; WYMANN, 1993; POWIS et al., 1994; STARLETS et al., 2006) e LY294002 (STARLETS et al., 2006; VLAHOS et al., 1994) de forma que a via AKT/PKB é indiretamente inibida pela desfosforilação de PIP3 que é convertido em PIP2 por PTEN (tumor supressor phosphatase and tensin homology deleted on chromosome ten) (STAMBOLIC et al., 1998) ou SHIP (SH2-domain-containing inositol polyphospatase 5-phosphatase) (ENGELMAN; LUO; CANTLEY, 2006; FAYARD et al., 2005).

\subsubsection{Sinalização da via jusante (downstream) da $A K T / P K B$}

AKT/PKB é a principal via que medeia a sobrevivência celular. Pode atuar de modo direto ou indireto por meio das seguintes vias: i) inativando BAD, uma proteína pró apoptótica da família Bcl-2; ii) ativando NF-KB através da regulação da quinase IKB (I-kappa-B kinase/IKK), o que resulta na transcrição de genes pró-sobrevivência; iii) fosforilando a proteína p21 e inibindo seus efeitos antiproliferativos; iv) fosforilando $\mathrm{Mdm}_{2}$ que no núcleo, leva à redução nos níveis de p53 e sua transcrição ou ainda, v) fosforilando mTOR (alvo da rapamicina em mamíferos), também relacionado ao crescimento celular (LUE et al., 2007; SCHWARTZ et al., 2009; STARLETS et al., 2006; VIVANCO; SAWYERS, 2002).

Um importante substrato "dowstream" (jusante) direto de AKT é MDM $M_{2}$, cuja fosforilação inibe p53, o fator supressor de tumor que ativa a apoptose ou impede o ciclo celular (VIVANCO; SAWYERS, 2002).

\subsection{MIF promove a sobrevivência celular ativando PI3K/AKT}

Em 2007, Lue e colaboradores demonstraram a inibição de apoptose e aumento da sobrevida celular em fibroblastos mediada por MIF com consequente ativação de PI3K/AKT. Quando as células foram tratadas com o inibidor da PI3K, LY294002, mesmo na presença de MIF, entraram precocemente em processo apoptótico, reforçando a importância da via AKT no papel desempenhado por MIF na sobrevivência celular. 
Por outro lado, a sobrevivência das células deciduais também foi analisada pelo nosso grupo de pesquisa, com relação à presença do trofoblasto. Foi realizada uma cocultura de células deciduais e células trofoblásticas do cone ectoplacentário sob a ação de um agente indutor de apoptose. Observou-se que na cocultura as células deciduais apresentaram um menor índice apoptótico na presença do indutor do que o observado nas culturas controle. $O$ aumento na sobrevivência das células deciduais parece, desta forma, ter sido mediado pelo trofoblasto (BORBELY et al., 2012). Este achado em conjunto com outros dados obtidos em nosso laboratório, mostrando a expressão de MIF na interface materno fetal principalmente pelas células trofoblásticas (FARIA et al., 2010) e a presença de receptores de MIF nas células deciduais (MARTUCCI, 2010), nos levou a elaborar a hipótese de que a presença de MIF nesta interface está relacionada a mecanismos envolvidos na homeostase desta unidade funcional, ativando a via de sinalização mediada por Akt de modo a promover sobrevivência celular e, contribuindo desta forma com o sucesso gestacional. 
2 OBJETIVOS 


\subsection{Objetivo geral}

Determinar se a via AKT é ativada por MIF nas células deciduais.

\subsection{Objetivos específicos}

a) Caracterizar a presença do complexo receptor para MIF nas células deciduais de camundongo mantidas in vitro;

b) avaliar se estas células expostas ao MIF recombinante de camundongo ativam a via AKT;

c) avaliar os efeitos de MIF nas células deciduais no que diz respeito a sobrevivência celular. 
3 MATERIAL E MÉTODOS 


\subsection{Reagentes e suas procedências}

Abcam Inc. (Cambridge, MA, USA): anticorpo policlonal anti MIF, anticorpo policlonal anti pan AKT, anticorpo policlonal anti $\mathrm{MDM}_{2}$, anticorpo policlonal anti$\mathrm{pMDM}_{2}$ (S166), todos produzidos em coelho. Amersham Biosciences (Uppsala, Suécia): azul de bromofenol, tris-hidroximetil-aminometano, tween-20, ECL Western Blotting Detection kit, Hyperfilm ECL high performance chemiluminescence. Bio-Rad Laboratories (CA, USA): padrão de peso molecular para proteínas Kaleidoscope, membrana de nitrocelulose, acrilamida. DAKO S/A (Glostrup, Dinamarca): anticorpo monoclonal antidesmina produzido em camundongo, kit LSAB (contém 2 itens: anticorpo secundário biotinilado universal anti lgG de coelho/camundongo/ cabra e streptoavidina-HRP), kit 3,3' diaminobenzidina (DAB). Merck KGaA (Darmstadt, Alemanha): anticorpo policlonal antifosfo-AKT1(SER473) produzido em coelho, Wortmannin, LY 294002, metanol, peróxido de hidrogênio $\left(\mathrm{H}_{2} \mathrm{O}_{2}\right)$, hematoxilina de Harris, eosina, hematoxilina de Mayer. Sigma Chemical Co. (St Louis, MO, EUA): antisoros anti alfa2 macroglobulina e antivimentina produzidos em cabra, albumina sérica bovina (BSA), paraformaldeído, tampão fosfato salina (PBS), tampão tris salina (TBS), collagenase tipo II, protease, azul de Trypan, coquetel inibidor de protease, Triton X-100, Meio Eagle modificado por Dulbecco - DMEM, lactato de cálcio, piruvato de sódio, insulina, albumina conjugada à isotiocianato de fluoresceína, persulfato de amônio, anticorpo monoclonal anti- $\beta$-actina produzido em camundongo, fenilmetanosulfonilfluorido (PMSF), ortovanadato de sódio, ácido deoxicolato de sódio, pirofosfato de sódio tetrabásico, fluoreto de sódio, coquetel inibidor de proteases, tris $\mathrm{HCl}$, Glicina, tetrametiletilenediamina (TEMED). Invitrogen (Carlsbad, CA, USA): anticorpo anti cabra conjugado a Alexa flúor 647 produzido em coelho, anticorpo anti-rato ligado a Alexa flúor 488 produzido em galinha, tripsina-EDTA, soro bovino fetal, dodecil sulfato de sódio (SDS). Vector Laboratories Inc. (Burlingame, CA, USA): meio de montagem Vectashield com "4',6-diamidino-2-phenylindole" (DAPI), IgG anticamundongo conjugada a fluoresceína produzida em cavalo, IgG anticamundongo conjugada a Texas red produzida em cavalo, IgG anticoelho conjugada a Texas red produzida em cabra, IgG anticoelho conjugada a fluoresceína produzida em cabra, IgG anti-rato conjugada a Texas red produzida em cabra. Promega Corporation (Madison, WI, USA): Cell Titer 96 solução aquosa para ensaio de proliferação celular (3-(4,5- 
dimetiltiazol-2-yl)-5-(3-carboximetoxifenil)-2-(4-sulfofenil)-2H-tetrazólio) / MTS). R\&D Systems Inc. (Minneapolis, MN, USA): proteína MIF recombinante de camundongo (mrMIF). F. Hoffmann-La Roche Ltd (Basel, Suíça): kit para detecção in situ de morte celular ligado à fluoresceína. Honeywell Riedel-de Haën (Morristown, NJ, USA): Cloreto de amônio. Bender MedSystems Gmbh (Vienna, Áustria): anticorpo monoclonal anti CD44 (V4) produzido em rato. BD Biosciences (Franklin Lakes, NJ, USA): anticorpo monoclonal anti CD74 produzido em rato, Mitos plus Serum Extender. Developmental Studies Hybridoma Bank (lowa City, IA, USA): anticorpo monoclonal anti citoqueratina endo A (TROMA I) produzido em rato. Thermo Fisher Scientific Inc. (Waltham, MA, USA): Permount $\AA$, Restore Plus Western Blot Stripping Buffer, BCA Protein Assay Reagent (bicinchoninic acid). Vitrocell-Embriolife (Campinas, SP, Brasil): Sulfato de Gentamicina, Anfotericina B, Penicilina/Estreptomicina. Santa Cruz Biotechnology (CA, USA): anticorpo policlonal anti Ki67 produzido em cabra, anticorpo secundário anti IgG de coelho conjugado a HRP produzido em cabra, anticorpo secundário anti lgG de camundongo conjugado a HRP produzido em cabra.

\subsection{Animais}

Neste estudo foram utilizados camundongos da linhagem CD-1 (Mus musculus domesticus) importados pela empresa LGC Scientific Supply, Inc. (Miami, FL, USA) do produtor Charles River Laboratories International, Inc. (Wilmington, MA, USA), mantidos no Biotério de Experimentação do Departamento de Biologia Celular e do Desenvolvimento, na temperatura de $23 \pm 2{ }^{\circ} \mathrm{C}$ e $55 \pm 5 \%$ de umidade, em ciclos de 12 horas de luz e 12 horas de escuro e sob regime de água e ração granulada ad libidium. Para o acasalamento, fêmeas virgens com aproximadamente três meses de idade foram colocadas na gaiola do macho (2:1) e na manhã seguinte foi pesquisada a presença de rolha vaginal, que determinou a metade do primeiro dia de gestação (dg). Um total de 120 fêmeas grávidas foi utilizado em todos os experimentos. 


\subsection{Comitê de ética}

Todos os procedimentos experimentais foram realizados de acordo com os princípios éticos estabelecidos pela Sociedade Brasileira de Ciências em Animais de Laboratório - SBCAL, e aprovados pela Comissão de Ética no Uso de Animais do Instituto de Ciências Biomédicas da Universidade de São Paulo (CEUA/ICB), coordenada pelo Conselho Nacional de Controle de Experimentação Animal CONCEA. Os procedimentos foram iniciados após licença cedida pelo CEUA/ICB.

\subsection{Obtenção das células deciduais e manutenção in vitro}

No dia 7.5 de gestação, as fêmeas foram sacrificadas por deslocamento cervical e laparotomizadas para obtenção dos sítios de implantação (Figura 3). Imediatamente após a exposição dos cornos uterinos, a porção mesometrial dos úteros gravídicos foi isolada para a obtenção de células deciduais de acordo com Borbely et al. (2012).

Figura 3 - Esquema do sítio de implantação

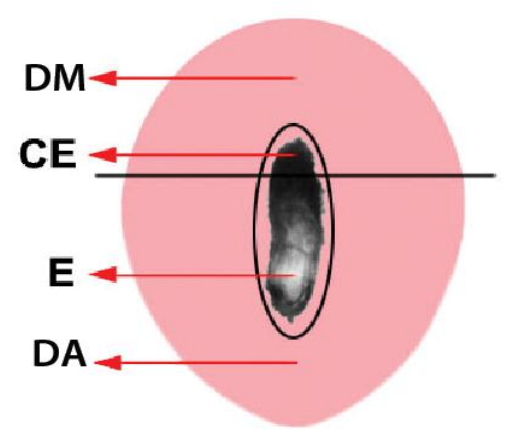

O esquema mostra um sítio de implantação indicando a decídua mesometrial (DM), a decídua anti mesometrial (DA), o cone ectoplacentário (CE) e o embrião (E).

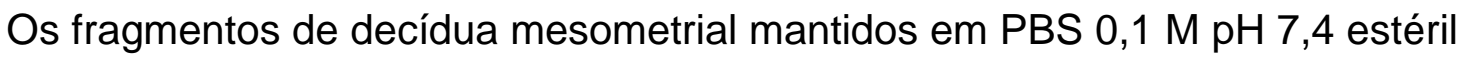
foram manualmente isolados dos demais tecidos maternos e fetais sob estereomicroscópio e transferidos para meio de cultivo DMEM estéril com 10\% SBF e antibióticos (penicilina/estreptomicina $0,5 \mathrm{mg} / \mathrm{mL}$ ). A porção decidual assim obtida foi fragmentada e submetida à solução de colagenase $\mathrm{IA}(3,6 \mathrm{mg} / \mathrm{mL})$ e protease $(1,2 \mathrm{mg} / \mathrm{mL})$ por 30 minutos a $37 \stackrel{\circ}{\circ}$ para a separação das células. $O$ processo enzimático foi interrompido pelo acréscimo DMEM com $20 \%$ de SBF. As amostras 
foram centrifugadas a 1.000 rpm por 5 minutos a $4 \stackrel{\circ}{\mathrm{C}}$ e o pellet ressuspendido em solução aquosa de hemólise com $0,83 \%$ de cloreto de amônio em meio de cultivo para remoção das hemácias. Após nova centrifugação, o pellet foi ressuspendido em $1 \mathrm{~mL}$ de DMEM suplementado e fresco para a contagem do número de células e estimativa das taxas de viabilidade pelo método de exclusão com Azul de Trypan.

Cones ectoplacentários, estruturas formadas exclusivamente por células trofoblásticas de origem epitelial, foram isolados da decídua, lavados com PBS 0,1 $\mathrm{M} \mathrm{pH} \mathrm{7,4} \mathrm{10 \%} \mathrm{de} \mathrm{SBF} \mathrm{a} 37 \stackrel{\circ}{\circ}$ e transferidos para placas de cultura contendo lamínulas (13 mm de diâmetro) em meio DMEM suplementado, por 24 horas em condições semelhantes as descritas para as células deciduais e utilizadas como controle em reações imunohistoquímicas.

\subsection{Delineamento experimental}

As células deciduais foram obtidas para manutenção em cultivo primário, plaqueadas na proporção de $2,5 \times 10^{5}$ células/poço em lamínulas ou diretamente sobre placas de cultivo de 24 poços (TPP Techno Plastics Products AG, Suíça) ou na proporção de $1 \times 10^{4}$ células/poço sobre placas de 96 poços (TPP Techno Plastics Products AG, Suíça). As células foram mantidas em DMEM estéril suplementado com lactato de cálcio $(0,5 \mathrm{mg} / \mathrm{mL})$, insulina $(0,2 \mu \mathrm{g} / \mathrm{mL})$, BSA $(4 \mathrm{mg} / \mathrm{mL})$, Mitos (1 $\mu \mathrm{g} / \mathrm{mL}$ ), L-glutamina $(0,1 \mathrm{mM})$, antibióticos (penicilina/estreptomicina $0,5 \mathrm{mg} / \mathrm{mL}$ ) e SBF 10\% em incubadora (Lab-Line Instruments modelo 6201, Kerala, India) em atmosfera úmida, a $37^{\circ} \mathrm{C}$ contendo $5 \%$ de dióxido de carbono.

Após $24 \mathrm{~h}$ as culturas tiveram seus meios substituídos e dependendo do ensaio experimental permaneceram em cultivo por adicionais 24 horas. Estes ensaios incluíram a determinação das taxas de viabilidade celular, de proliferação, de morte por apoptose e necrose e expressão de proteínas em culturas acrescidas ou não de: proteína MIF recombinante de camundongo - mrMIF ou inibidores de fosfatidilinositol 3 quinase (PI3K): LY294002 (LY) e Wortmannin (WT) ou ambos associados: mrMIF + LY + WT. Experimentos também foram realizados na presença de peróxido de hidrogênio, utilizado como indutor de morte celular. Cada ensaio foi realizado em triplicata amostral e experimental.

Durante o período experimental, as células aderidas foram avaliadas quanto às características morfológicas e quanto à pureza da população celular isolada, 
utilizando-se como marcadores a expressão de citoqueratina (presente em células epiteliais), vimentina (células de origem mesenquimal) e alfa 2-macroglobulina e desmina (marcadores específicos de células deciduais) (ABRAHAMSOHN; ZORN, 1993; GU et al., 1992; OLIVEIRA et al., 2000; TANG; GULLER; GURPIDE, 1993; THOMAS, 1993).

\subsection{Caracterização das células mantidas in vitro}

\subsubsection{Análise morfológica}

Para a análise morfológica, as lamínulas contendo as células deciduais foram removidas do sistema de cultivo após 24 e $48 \mathrm{~h}$, fixadas em $4 \%$ de paraformaldeído em PBS $0,1 \mathrm{M} \mathrm{pH} 7,4$, coradas com hematoxilina-eosina, desidratadas, diafanizadas, montadas em lâmina histológica com Permount® ${ }^{\circledR}$ e analisadas sob microscopia de luz convencional (Axioskop2, Zeiss, Alemanha). As células mantidas em incubadora foram analisadas sob microscopia de fase (Axiovert S100, Zeiss, Alemanha) a as imagens capturadas com câmera AxioCamERc5s (Zeiss, Alemanha).

\subsubsection{Imunolocalização de antígenos utilizados como marcadores das células deciduais}

Para a imunolocalização de vimentina (antígenos utilizados como marcadores de células mesenquimais), desmina e alfa2-macroglobulina (antígenos utilizados como marcadores de células deciduais), as células mantidas sobre lamínulas foram

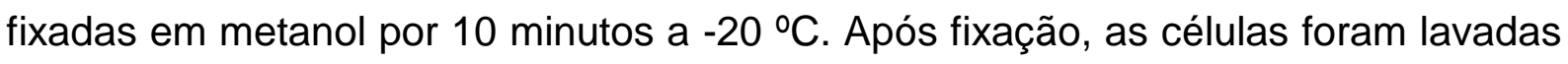
em PBS 0,1 M pH 7,4 e incubadas em 1\% BSA em PBS, por 30 minutos, a temperatura ambiente, para bloqueio das ligações inespecíficas. As concentrações dos anticorpos primários utilizadas neste ensaio experimental estão compiladas na Quadro 1. Todos os anticorpos foram diluídos em 1\% BSA em PBS e utilizados para incubação das culturas por 1 hora e 30 minutos, a temperatura ambiente. Após 3 lavagens com PBS as culturas foram novamente incubadas por 45 minutos, a temperatura ambiente, em câmara escura, com os anticorpos secundários conforme Quadro 1, todos diluídos 1:50 em BSA 1\% em PBS. As lamínulas contendo as células foram então lavadas com PBS novamente, montadas com o meio de 
montagem Vectashield® com DAPI e analisadas em microscópio de fluorescência (Axioskop 2, Zeiss, Alemanha). Como controle negativo o anticorpo primário foi omitido da reação.

Para confirmar a ausência de células de origem epitelial no cultivo de células deciduais, também foi realizada imunomarcação para citoqueratina (marcador de células epiteliais). Como controle positivo, foram utilizados cones ectoplacentários cultivados por 24 horas, conforme descrito no item 3.3. Semelhantemente aos demais marcadores, após fixação, permeabilização e bloqueio das ligações inespecíficas, as culturas de decídua e as de cone ectoplacentário foram incubadas com o anticorpo anti-citoqueratina (TROMA1) diluído em BSA 1\% em PBS conforme Quadro 1, por 1 hora e 30 minutos. Após lavagens em PBS foi realizada a incubação com o anticorpo secundário (Quadro 1) diluído também em BSA 1\% em PBS por 45 minutos, em câmara escura, após período o qual as culturas foram lavadas novamente e montadas com VectashieldA com DAPI e analisadas em microscópio de fluorescência (Axioskop 2, Zeiss, Alemanha). Como controle negativo o anticorpo primário foi omitido da reação.

Quadro 1 - Anticorpos primários e secundários utilizados nas reações de imunomarcação

\begin{tabular}{|c|c|c|c|}
\hline & ANTICORPO PRIMÁRIO & DILUIÇÃO & ANTICORPO SECUNDÁRIO DILUÍDO 1:50 \\
\hline 1 & IgG de rato contra CD44 var (v4), monoclonal & $1: 75$ & IgG de galinha conjugado a Alexa fluor 488 anti-rato \\
\hline 2 & IgG de rato anti-CD74, monoclonal & $1: 25$ & IgG de cabra conjugado a Texas red anti-rato \\
\hline 3 & IgG de coelho anti-MIF, policlonal & $1: 50$ & IgG de cabra conjugado a Texas red anti-coelho \\
\hline 4 & Soro de cabra anti alfa-2-macroglobulina & $1: 50$ & IgG de coelho conjugado a Alexa fluor 647 anti-cabra \\
\hline 5 & IgG de camundongo anti-Desmina, monoclonal & $1: 50$ & IgG de cavalo conjugado a Fluoresceína anti-camundongo \\
\hline 6 & Soro de cabra anti-vimentina & $1: 50$ & IgG de coelho conjugado a Alexa fluor 647 anti-cabra \\
\hline 7 & IgG de rato anti-citoqueratina (TROMA I), monoclonal & $1: 200$ & IgG de galinha conjugado a Alexa flúor 488 anti-rato \\
\hline 8 & IgG de coelho anti pAKT1 (SER473), policlonal & $1: 75$ & IgG de cabra conjugado a Fluoresceína anti-coelho \\
\hline 9 & IgG de coelho anti pan-AKT, policlonal & $1: 100$ & IgG de cabra conjugado a Fluoresceína anti-coelho \\
\hline 10 & IgG de coelho anti $\mathrm{pMDM}_{2}$ (SER166), policlonal & $1: 100$ & IgG de cabra conjugado a Fluoresceína anti-coelho \\
\hline 11 & IgG de coelho anti-MDM 2 , policlonal & $1: 75$ & IgG de cabra conjugado a Fluoresceína anti-coelho \\
\hline 12 & IgG de cabra anti Ki-67, policlonal & $1: 50$ & Universal LSAB, anti-coelho/camundongo/cabra \\
\hline
\end{tabular}




\subsection{Ensaios de morte celular}

3.6.1 Reação de TUNEL para identificação de células em processo de morte por apoptose

Para identificar a melhor concentração e avaliar a ação de MIF sobre o processo de morte celular por apoptose as células plaqueadas sobre lamínulas receberam após 24 horas meio com restrição de SBF por 1 hora (DMEM acrescido de $0,1 \%$ de SBF) e em seguida foram tratadas com mrMIF nas seguintes concentrações: 25, 50, 100 e $200 \mathrm{ng} / \mathrm{mL}$. Amostras que não receberam mrMIF foram utilizadas como controle. Após $24 \mathrm{~h}$ de tratamento as células foram lavadas em PBS e fixadas em $4 \%$ paraformaldeído tamponado e submetidas à reação de TUNEL (terminal deoxynucleotidyl transferase dUTP Nick end labeling). Para isto, utilizou-se - kit para detecção in situ de morte celular ligado à fluoresceína conforme recomendações do fabricante: lavagem em PBS 0,1 M pH 7,4, permeabilização por 2 minutos sobre gelo com Triton X-100 0,1\% em solução aquosa de citrato $0,1 \%$, novas lavagens em PBS, incubação no "mix" constituído por $4 \mu \mathrm{L}$ de enzima para 10 $\mu \mathrm{L}$ de marcador por 1 hora a $37^{\circ} \mathrm{C}$ em câmara úmida e escura e, após novas lavagens com PBS, montagem das lamínulas com meio Vectashield® com DAPI. As células foram analisadas ao microscópio de fluorescência (Axioskop, Zeiss, Alemanha), e as imagens capturadas através do sistema AxioVision (Zeiss, Alemanha). A quantificação foi realizada a partir do número de células reativas, ou seja, células em apoptose, sobre o número total de células por campo. Um total de cinco campos randomicamente selecionados em um aumento de $100 \mathrm{X}$, e um total de cinco culturas para cada tratamento foram analisadas para o cálculo dos valores médios percentuais.

3.6.2 Coloração com albumina-FITC para identificação de células em processo de morte por necrose

Para o ensaio de necrose com o objetivo de analisar o grau de citoxicidade e interferência dos procedimentos na sobrevivência celular, após tratamento conforme descrito acima na seção 3.6.1, as células deciduais foram incubadas ainda em cultivo com albumina conjugada à isotiocianato de fluoresceína (FITC) na 
concentração de $3 \mathrm{mg} / \mathrm{mL}$ por 5 minutos, lavadas, fixadas em $4 \%$ paraformaldeído tamponado, e montadas com Vectashield $\Theta$. As culturas foram então observadas em microscópio de fluorescência (Axioskop, Zeiss, Alemanha). Células coradas e o total de células por campo microscópico foram contadas em cinco campos randomicamente selecionados em um total de cinco culturas para cada tratamento, para o cálculo dos valores médios percentuais.

\subsection{Viabilidade das células deciduais}

\subsubsection{Viabilidade em função do tempo de cultivo}

Para análise da viabilidade celular em função do tempo de cultivo, $2 \times 10^{5}$ células deciduais foram cultivadas em placas de 24 poços por 24, 48, 72, 96 e 120 horas. Após cada período as células foram lavadas com PBS 0,1 M pH 7,4 e destacadas da placa utilizando-se Tripsina-EDTA $0,5 \%$ por 5 minutos a $37^{\circ} \mathrm{C}$. Cada amostra de cada tempo experimental foi ressuspendida em meio fresco DMEM suplementado conforme descrito na seção 3.4, e quantificadas em câmara de Neubauer para a contagem do número de células e avaliação da taxa de viabilidade celular pelo método de exclusão com azul de Trypan $0,4 \%$. Neste método as células mortas são coradas e, portanto, excluídas da contagem. Os dados obtidos foram normatizados em função do número de células viáveis inicialmente inseridos nas placas de cultivo e suas médias comparadas entre si em relação ao tempo de cultivo.

\subsubsection{Imunolocalização de Ki67}

Para a imunolocalização de Ki67, as células cultivadas sobre lamínulas em placa de 24 poços, por 24 horas foram fixadas em $4 \%$ paraformaldeído tamponado

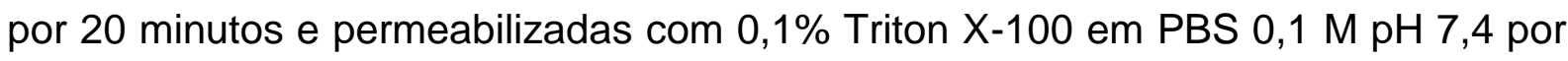
5 minutos. Após sucessivas lavagens foram incubadas com metanol e peróxido de hidrogênio na proporção 1:1 para bloqueio da peroxidase endógena, e após novas lavagens em PBS, submetidas à solução de BSA 1\% em PBS, para bloqueio das ligações inespecíficas. As culturas foram então incubadas por 1 hora e 30 minutos no anticorpo primário anti-Ki67 e respectivo anticorpo secundário conforme descrito 
na Quadro 1. Após lavagens em PBS, as células foram incubadas com estreptoavidina-HRP por 30 minutos e a revelação enzimática da peroxidase realizada com tetracloreto de 3,3'diaminobenzidina (DAB) por 10 minutos. As células foram contracoradas com hematoxilina de Mayer por 10 minutos e analisadas em microscópio de luz convencional (Axioskop 2, Zeiss, Alemanha). Como controle negativo o anticorpo primário foi omitido da reação.

\subsubsection{MTS (3-(4,5-dimetiltiazol-2-yl)-5-(3-carboximetoxifenil)-2-(4-sulfofenil)-2H- tetrazólio)}

Para avaliar o grau de interferência de MIF no processo de viabilidade celular, foram mantidas $1 \times 10^{4}$ células deciduais por poço, em placas com 96 poços. Após as primeiras 24 horas em cultura, o meio foi substituído por outro com restrição de SBF (DMEM acrescido de $0,1 \%$ de SBF) aonde as culturas permaneceram por $1 \mathrm{~h}$. A seguir as células foram lavadas com PBS $0,1 \mathrm{M} \mathrm{pH} \mathrm{7,4} \mathrm{e} \mathrm{submetidas} \mathrm{ao} \mathrm{tratamento}$ com mrMIF nas concentrações de 25, 50, 100 e $200 \mathrm{ng} / \mathrm{mL}$ em meio de cultivo por adicionais 24 horas. A análise foi então realizada pela reatividade do MTS, medida por absorbância, aplicado a 10\% em meio de cultivo, após incubação por 3 horas a $37^{\circ} \mathrm{C}$. A leitura foi realizada em leitor de microplacas (EL 800 G, BioTek Instruments Inc., Winooski, VT, USA) a $490 \mathrm{~nm}$. Como referência utilizou-se meio de cultivo com MTS a $10 \%$ em poços sem células, sendo os dados normatizados com a amostra que não recebeu tratamento, ou seja, foi incubada somente com meio de cultivo suplementado sem mrMIF. Neste ensaio os experimentos foram repetidos três vezes em diferentes ocasiões e realizados em quadriplicata.

\subsection{Expressão de MIF e seus receptores pelas células deciduais in vitro}

Para a imunolocalização de MIF, as células mantidas sobre lamínulas foram fixadas em metanol por 10 minutos a $-20^{\circ} \mathrm{C}$. Após fixação, as células foram lavadas em PBS 0,1M pH 7,4 e incubadas em 1\% BSA em PBS, por 30 minutos, a temperatura ambiente, para bloqueio das ligações inespecíficas. $O$ anticorpo antiMIF foi diluído 1:50 em 1\% BSA em PBS e utilizado para incubação das culturas por 1 hora e 30 minutos, a temperatura ambiente. Após três lavagens com PBS as culturas foram novamente incubadas por 45 minutos, a temperatura ambiente, com o 
anticorpo secundário conforme Quadro 1, diluído 1:50 em BSA 1\% em PBS. As lamínulas contendo as células cultivadas foram então lavadas com PBS novamente, montadas com o meio de montagem VectashieldA com DAPI e analisadas em microscópio de fluorescência (Axioskop 2, Zeiss, Alemanha). Como controle negativo o anticorpo primário foi omitido da reação.

Para o complexo receptor CD44/CD74, as células cultivadas sobre lamínulas em placa de 24 poços, por 24 horas, foram fixadas em paraformaldeído 4\% em PBS 0,1 M pH 7,4 por 20 minutos a temperatura ambiente. Após fixação, as células foram lavadas em PBS 0,1M pH 7,4 e incubadas em albumina sérica bovina (BSA) 1\% em PBS, por 30 minutos a temperatura ambiente, para bloqueio das ligações inespecíficas. O anticorpo primário anti CD44 foi incubado e homogeneizado com o respectivo anticorpo secundário anti rato conjugado a Alexa flúor 488 em um tubo, diluídos em BSA 1\% em PBS, e em seguida aplicado às células para incubação por 1 hora e 30 minutos. Após lavagem em PBS $0,1 \mathrm{M}$ pH 7,4, as culturas foram incubadas por 1 hora e 30 minutos com anticorpo anti CD74 (após sua incubação com o anticorpo secundário anti rato conjugado a Texas red em um tubo diluídos em BSA 1\% em PBS). A concentração dos anticorpos secundários foi sempre de 1:50 e a dos anticorpos primários estão compiladas na Quadro 1. Os procedimentos foram realizados a temperatura ambiente em câmara escura. As lamínulas contendo as células cultivadas foram então montadas com o meio de montagem Vectashield® e analisadas em microscópio de fluorescência (Axioskop 2, Zeiss, Alemanha). Como controle negativo o anticorpo primário foi omitido da reação.

\subsection{Ensaios de sobrevivência celular mediada pelo MIF}

Para testar os efeitos do MIF como mediador de sobrevivência celular, injúria foi induzida nas células cultivadas através da administração de peróxido de hidrogênio $\left(\mathrm{H}_{2} \mathrm{O}_{2}\right)$. Para determinar a concentração adequada desta espécie reativa de oxigênio, capaz de afetar a viabilidade das células cultivadas sem destruir completamente a cultura, curvas dose-resposta em função da morte por apoptose e necrose foram estimadas em ensaios utilizando as concentrações de 0, $250 \mu \mathrm{M}, 500$ $\mu \mathrm{M}, 1 \mathrm{mM}, 2 \mathrm{mM}$ e $4 \mathrm{mM}$ de $\mathrm{H}_{2} \mathrm{O}_{2}$ em meio DMEM suplementado, após restrição de SBF por 1 hora. Os efeitos do MIF sobre a indução de morte pelo $\mathrm{H}_{2} \mathrm{O}_{2}$ foram 
avaliados após a administração de $25 \mathrm{ng} / \mathrm{mL}$ de $\mathrm{mrMIF}, 24 \mathrm{~h}$ antes da administração de $\mathrm{H}_{2} \mathrm{O}_{2}$ e após restrição de SBF por 1 hora.

\subsection{Expressão proteica nas células deciduais tratadas com mrMIF}

\subsubsection{Tratamento com mrMIF}

Para esta análise, após 24 horas de cultivo e restrição de SBF por 1 hora, as células foram tratadas com os inibidores da proteína PI3K: 50 mM de LY294002 (STARLETS et al., 2006; VLAHOS et al., 1994) e 100 nM de Wortmannin (POWIS et al., 1994; STARLETS et al., 2006) juntos, por 15 minutos seguido por tratamento com $25 \mathrm{ng} / \mathrm{mL}$ de mrMIF, por adicionais $15 \mathrm{~min}$. Controles foram realizados utilizando-se ensaios similares que: i) não receberam mrMIF ou inibidores de PI3K, ii) que não receberam mrMIF, apenas os inibidores de PI3K e, iii) que receberam mrMIF, mas não os inibidores de PI3K. Os experimentos foram realizados em triplicatas e repetidos em diferentes ocasiões.

\subsubsection{Análise por imunofluorescência}

Após os tratamentos, as células foram lavadas com PBS 0,1M, fixadas em 4\% paraformaldeído tamponado por 20 min, permeabilizadas com 0,1\% Triton X-100 em PBS 0,1 M pH7,4 por 5 min e seguiram protocolo específico para imunomarcação conforme descrito na seção 3.5 .2 e Quadro 1, para a imunolocalização das proteínas pAKT, AKT, MDM 2 e $\mathrm{pMDM}_{2}$.

\subsubsection{Análise por Western Blotting}

Para obtenção das amostras para análise da expressão proteica de AKT, $\mathrm{pAKT}, \mathrm{MDM}_{2}$ e $\mathrm{pMDM}_{2}$ nas células deciduais após tratamento com mrMIF conforme descrito no item 3.10.1, foram lavadas três vezes com PBS $0,1 \mathrm{M} \mathrm{pH} \mathrm{7,4} \mathrm{e} \mathrm{lisadas} \mathrm{na}$ placa de cultura sobre gelo com tampão RIPA (NP40 1\%, Na-deoxicolato 0,25\%, $\mathrm{NaF} 2 \mathrm{mM}$, NaCl $150 \mathrm{mM}$, PMSF $1 \mathrm{mM}, \mathrm{Na}_{3} \mathrm{VO}_{4} 1 \mathrm{mM}$, EDTA $1 \mathrm{mM}$ e Tris-HCl 50 $\mathrm{mM} \mathrm{pH}$ 7,4) acrescido de um coquetel inibidor de protease, por 10 minutos. A suspensão foi centrifugada a $11000 \mathrm{rpm}$ por 20 minutos a $4^{\circ} \mathrm{C}$, e a partir do 
sobrenadante foi determinada a concentração de proteína total de cada amostra utilizando-se o kit BCA Protein Assay Reagent (bicinchoninic acid) a qual leitura foi realizada em leitor de microplacas a 562 nm (EL 800 G, BioTek Instruments Inc., Winooski, VT, USA). Utilizando os dados desta quantificação as amostras foram preparadas de modo que $20 \mu \mathrm{L}$ contivessem $30 \mu \mathrm{g}$ de proteína total em um tampão de amostra (Tris $85 \mathrm{mM}$, DTT $40 \mathrm{mM}$, glicerol 17\%, SDS 0,1\% e azul de bromofenol 0,4\% diluídos em água Milli-Q), submetidas a $95 \stackrel{\circ}{\circ}$ por 5 minutos em placa de banho seco (DB-2 ${ }^{\mathrm{a}}$, TECHNE, Bibby Scientific Limited, Staffordshire, UK) e armazenadas a $-80 \stackrel{\circ}{\circ}$. Em uma etapa subsequente, as proteínas presentes nas amostras foram separadas por eletroforese SDS-PAGE em gel de poliacrilamida a $10 \%$ a uma voltagem de $110 \mathrm{~V}$ (Fonte Power Pac HC, Bio-Rad Laboratories, CA, USA) durante cerca de 1 hora e 15 minutos. As proteínas já separadas pelo peso molecular foram transferidas para uma membrana de nitrocelulose de 0,45 $\mu \mathrm{m}$ (Merck Millipore Headquarters, Billerica, MA, USA) a uma voltagem de $100 \mathrm{~V}$ por 1 hora, sob gelo, a $4 \stackrel{\circ}{ } \mathrm{C}$, que foi corada com solução de Ponceau Red a 0,5\% para constatação da conclusão da transferência e sua imagem capturada. No blotting, a membrana foi lavada duas vezes com 0,1 M TBS pH 7,5 com Tween 20 0,1\% (TBST) e incubada em solução de bloqueio das reações inespecíficas contendo $5 \%$ de leite desnatado (para as proteínas não fosforiladas e $\beta$-actina) ou BSA $2 \%$ (para as proteínas fosforiladas), ambas soluções em TBST por 1 hora a temperatura ambiente sob agitação. Após o período de bloqueio, a membrana foi incubada overnight a $4 \stackrel{\circ}{\mathrm{C}}$ nos anticorpos primários diluídos na respectiva solução de bloqueio sob agitação, e no dia seguinte após sucessivas lavagens nos anticorpos secundários diluídos também em solução de bloqueio, incubado por 1 hora e 30 minutos sob agitação a temperatura ambiente. As diluições dos anticorpos primários e secundários estão descritas na Quadro 2. A revelação foi executada com kit ECL preparado na proporção de 40:1 (solução A para solução B, respectivamente), conforme orientações do fabricante (Amersham Biosciences Uppsala, Suécia) a qual a membrana ficou exposta por 1 minuto e a partir da qual as bandas foram detectadas por quimioluminescência impressas em filme de raio-X. A análise foi realizada por densitometria: os filmes foram escaneados em Multifuncional Canon modelo Image Runner 1025iF (Canon USA Inc., NY, USA) e as bandas de proteínas reconhecidas pelo anticorpo e impressas no filme foram quantificadas com o auxílio do software Image $\mathrm{J}(\mathrm{NIH}$, Bethesda, USA). A média dos valores obtidos foi utilizada 
para cálculo da razão entre a proteína na sua forma fosforilada pela não fosforilada, normatizadas pela $\beta$-actina, utilizada como proteína de referência.

Quadro 2 - Anticorpos primários e secundários utilizados nas reações de Western Blotting

\begin{tabular}{|lccc|}
\hline & Anticorpo Primário & Diluição & Anticorpo Secundário Diluído 1:2000 \\
$\mathbf{1}$ & IgG de camundongo anti- $\beta$-actina, Clone AC-15 monoclonal & $1: 5000$ & IgG de cabra conjugado a HRP anti-camundongo \\
$\mathbf{3}$ & IgG de coelho anti pMDM 2 (SER166), policlonal & $1: 500$ & IgG de cabra conjugado a HRP anti-coelho \\
$\mathbf{4}$ & IgG de coelho anti-MDM, policlonal & $1: 250$ & IgG de cabra conjugado a HRP anti-coelho \\
$\mathbf{5}$ & IgG de coelho anti pAKT1 (SER473), policlonal & $1: 500$ & IgG de cabra conjugado a HRP anti-coelho \\
\hline
\end{tabular}

\subsection{Análise estatística}

Em todos os ensaios, o total de células reativas em função do total de células por campo microscópico foi utilizado como meio de avaliar os diferentes parâmetros celulares. Foram contados pelo menos cinco campos por cultura, selecionados randomicamente, em culturas realizadas em pelo menos três diferentes ocasiões. A análise quantitativa da expressão proteica foi realizada a partir dos valores médios obtidos da relação entre a proteína analisada e a proteína de referência ( $\beta$-actina), após a normatização, também foi analisada a relação entre a forma fosforilada e a forma não-fosforilada correspondente. As médias e os desvios padrão foram calculados utilizando-se o programa Excel for Windows 2007 (Microsoft Corporation, Charlotte, North Carolina, USA). Os valores foram comparados pelo teste ANOVA que foram confirmados pelo Teste Kruskal -Wallis utilizando-se o programa GraphPad InsStat 3.0 (GraphPad Software, San Diego, California, USA), considerados estatisticamente significantes os valores de $p \leq 0,05$. 
4 RESULTADOS 


\subsection{Caracterização das células deciduais}

Durante as primeiras $24 \mathrm{~h}$ de cultivo as células deciduais aderiram à placa de cultura e mostraram morfologia bastante homogênea, embora variassem em dimensões (Figura 5A). Estas células distribuíam-se sobre a placa de cultura, apresentando-se fusiformes ou triangulares com projeções afuniladas em suas extremidades. Os núcleos em geral arredondados exibiam nucléolos evidentes (Figura 5B). Neste período experimental, os contatos entre células pareceram ocasionais, não constituindo, desta forma, organização em camadas (Figuras 4A-B, 5A-B). Em função do tempo de manutenção em cultivo, entretanto, houve confluência das células, que preencheram completamente a placa de cultura, estruturando-se em camadas (Figuras 4C-E). A análise mais pormenorizada destas células mostra que ocorreu hipertrofia celular com as células agora exibindo formas poligonais heterogêneas (Figura 4C).

Valores obtidos a partir da contagem de células viáveis em função do tempo de cultivo e plotados na Figura 5D mostram que nas condições utilizadas, as culturas se mantém estáveis por $48 \mathrm{~h}$ após o que há um significativo $(p<0,05)$ decréscimo no número de células viáveis na cultura. No entanto, a imunolocalização da proteína Ki-67, um marcador de proliferação celular, presente durante todas as fases ativas do ciclo celular ( $\mathrm{G} 1, \mathrm{~S}, \mathrm{G} 2$ e mitose), mas não nas células em repouso (G0) indica que a grande maioria das células cultivadas aderidas encontra-se ativa (Figura 5C). 
Figura 4 - Cultura de células deciduais
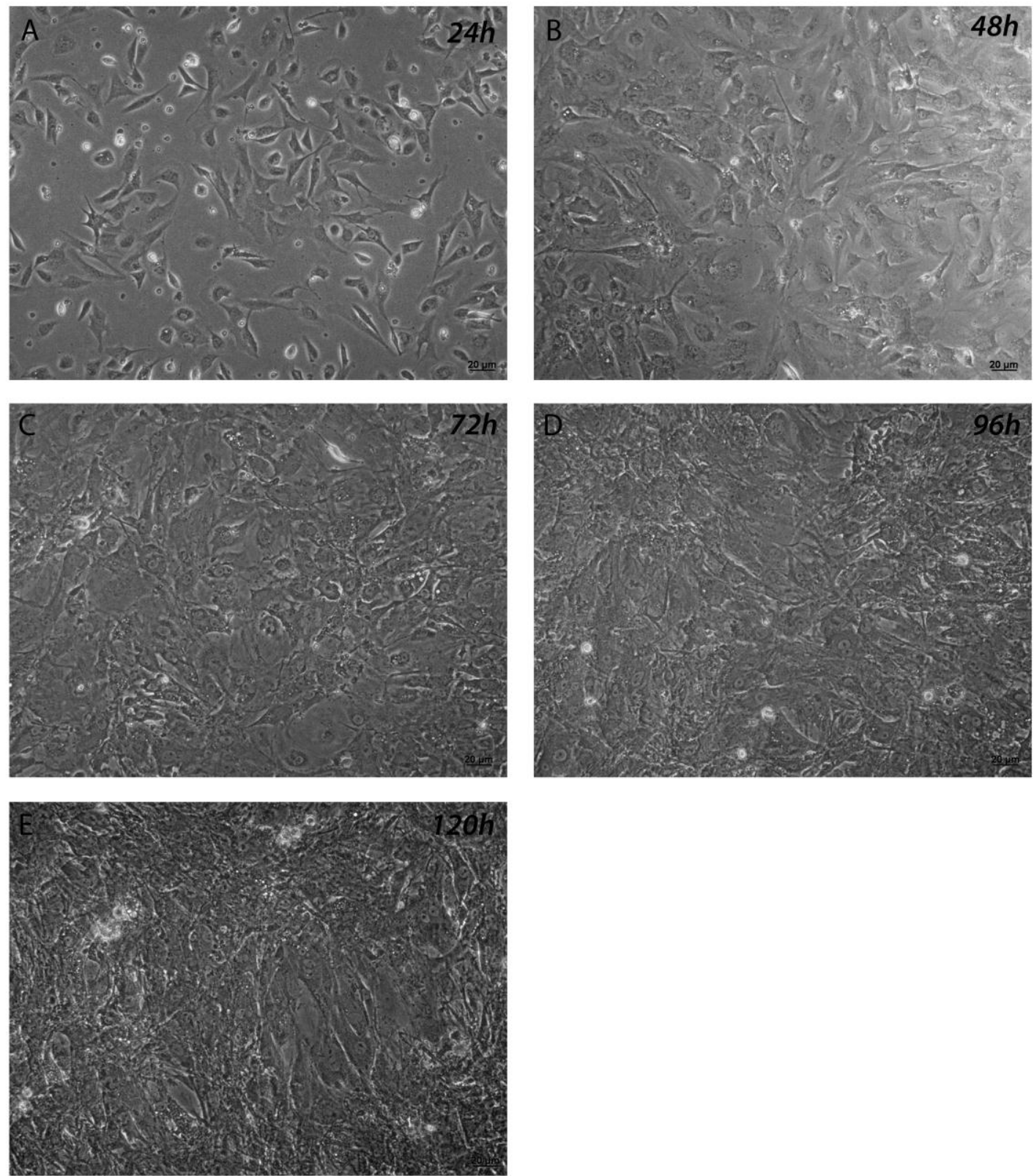

As fotomicrografias mostram células deciduais in vitro com 24 (A) e 48 horas (B) em subconfluência, e em confluência após 72 (C), 96 (D) e 120 horas (E). Aumento de 100X. 
Figura 5 - Viabilidade das células deciduais
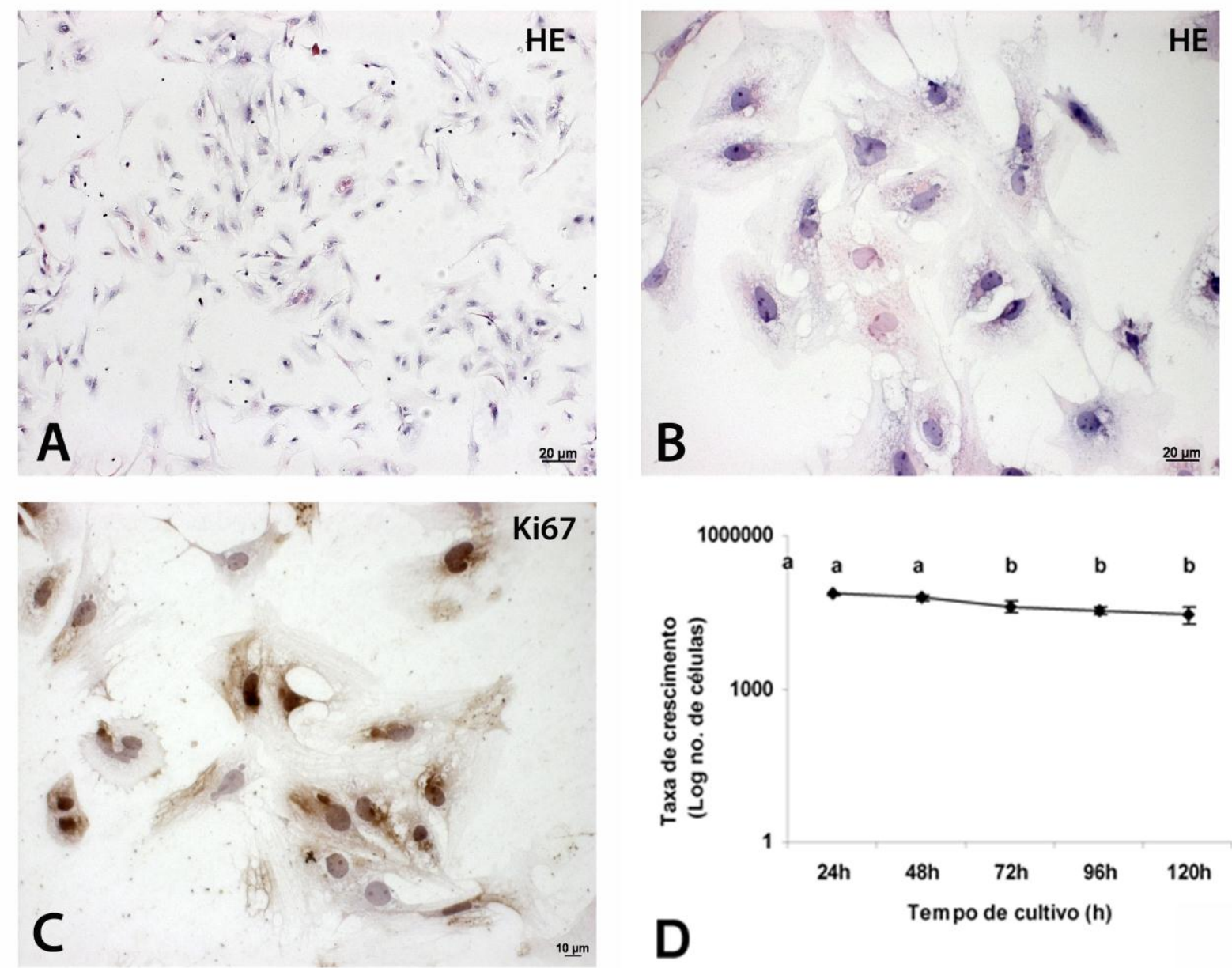

As fotomicrografias A e B representam culturas de células deciduais cultivadas por 24 horas, e coradas pela Hematoxilina e Eosina (HE). Observar em C células deciduais cultivadas por $24 \mathrm{~h}$ e submetidas à reação imunohistoquímica para localização do antígeno de proliferação celular Ki67 (método enzimático com peroxidase, contracorado com Hematoxilina de Mayer). Notar a presença de núcleos reativos corados em marrom escuro. (D) O gráfico mostra a curva de crescimento das células cultivadas durante 120 horas de cultivo ( $n=3$, valores médios \pm desvio padrão). Letras diferentes indicam diferenças estatisticamente significantes, teste $t$ de Student $(p<0,05)$.

A natureza das células cultivadas foi comprovada por meio de reações imunohistoquímicas para a localização de filamentos intermediários de vimentina, que identifica células de origem mesenquimal (Figura 6A), desmina (Figura 6B) e alfa2 macroglobulina (Figura $6 \mathrm{C}$ ), que identificam células deciduais. A contagem das células reativas para cada tipo de marcador foi de $100 \%$ para as células vimentina e alfa2 macroglobulina e de $87 \%$ para as células desmina-reativas (Figura 6E).

Ainda, para avaliar a presença de possíveis contaminantes epiteliais, a presença de células reativas para filamentos intermediários de citoqueratina foi 
pesquisada; no entanto, não foram observadas células reativas em nenhuma das culturas analisadas (Figuras 6D, F). Como controle positivo da reação utilizou-se fragmentos de cones ectoplacentários, de origem epitelial. Estas células foram reativas ao anticorpo anti citoqueratina (Figura 6D, detalhe).

\subsection{Expressão de MIF e seus receptores pelas células deciduais in vitro}

As células deciduais foram reativas aos anticorpos anti CD44 (Figura 7A) e anti CD74 (Figura7B), respectivamente, na proporção de 94\% e 67\% (Figura 7E). Quando realizada a dupla marcação, observou-se que cerca de $50 \%$ destas células colocalizavam os dois receptores, evidenciados em amarelo, resultado da sobreposição dos fluorocromos verde e vermelho (Figura 7C). As células deciduais também se mostraram reativas ao anticorpo anti MIF (Figuras 7D-E).

\subsection{Determinação da concentração ideal de mrMIF}

O ensaio de MTS mostrou que mrMIF nas concentrações de 25, 50 e 100 $\mathrm{ng} / \mathrm{mL}$ manteve a viabilidade das células deciduais cultivadas em níveis maiores do que o observado no grupo controle que não recebeu MIF $(0 \mathrm{ng} / \mathrm{mL})$ ou que o recebeu na concentração de $200 \mathrm{ng} / \mathrm{mL}$ (Figura $8 \mathrm{~A}$ ). Por outro lado, a redução dos níveis de apoptose nas culturas foi estatisticamente significante $(p<0,05)$ para todos os grupos analisados em função do controle que não recebeu MIF (Figura 8B). A presença de células com membrana rompida identificadas pela presença de albumina-FITC, características de células em processo de morte celular por necrose, ao contrário, mostrou índices significantemente maiores em relação ao controle apenas na concentração de $200 \mathrm{ng} / \mathrm{mL}$. Ainda, destacou-se o baixo índice de células rompidas quando à cultura foi adicionado MIF na concentração de $25 \mathrm{ng} / \mathrm{mL}$ (Figura $8 C)$. 
Figura 6 - Caracterização das células deciduais
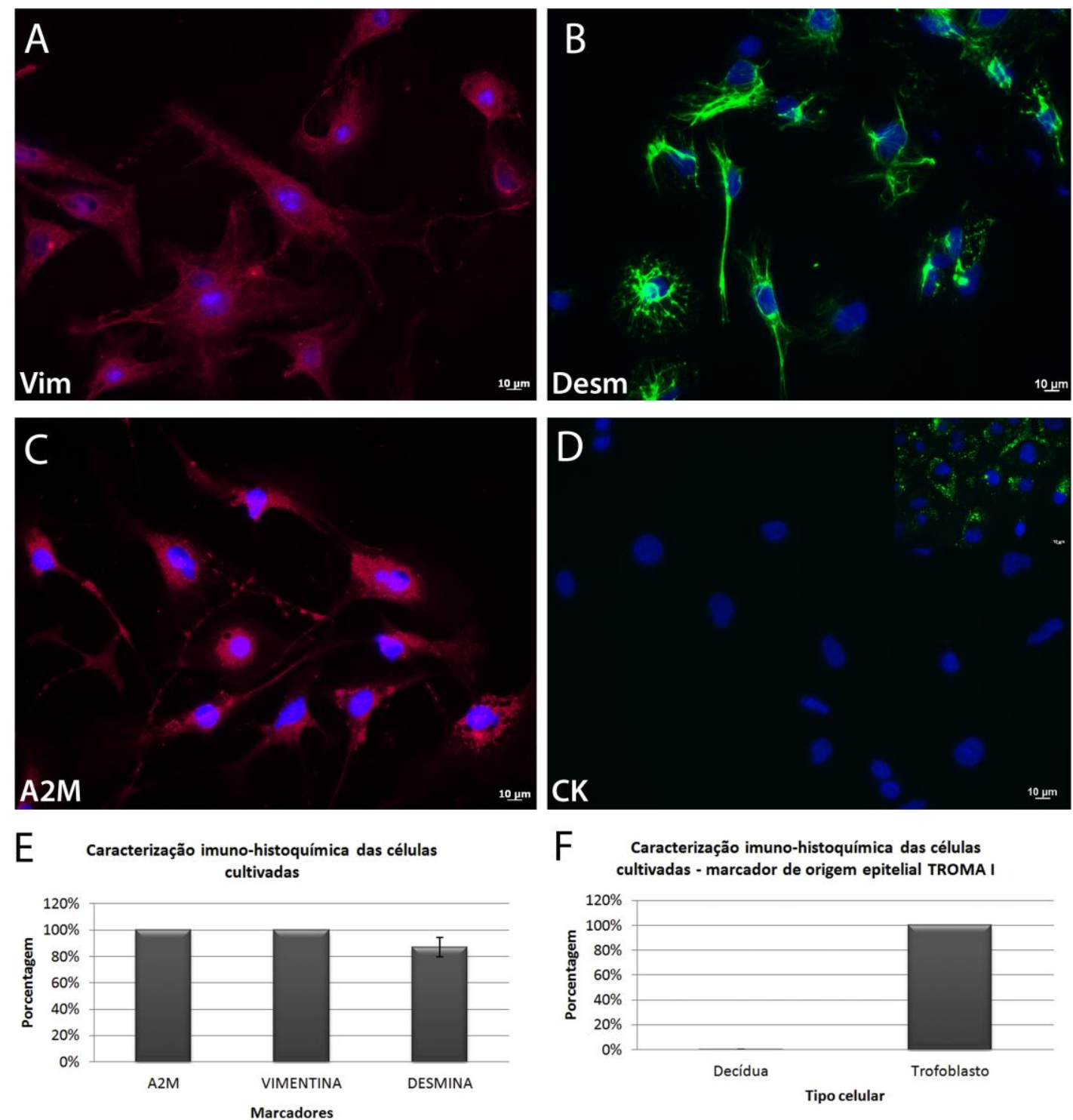

$\mathrm{F}$

- Caracterização imuno-histoquímica das células cultivadas - marcador de origem epitelial TROMA I

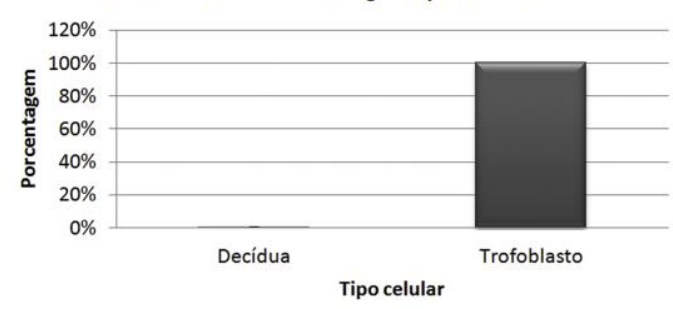

(A-D) As fotomicrografias mostram a presença de marcadores de células de origem mesodérmica como os filamentos intermediários de vimentina (A, vim), de desmina (B, desm) e alfa-2macroglobulina (C, A2M), típicos de células deciduais e a ausência de filamentos de citoqueratina (D), que só são observados nas células trofoblásticas do cone ectoplacentário (D, CK, canto superior direito). (E-F) Os gráficos representam valores percentuais médios de células reativas para cada marcador em relação ao total de células presentes por campo microscópico $(n=3)$. 
Figura 7 - Expressão de MIF e seus receptores pelas células deciduais cultivadas
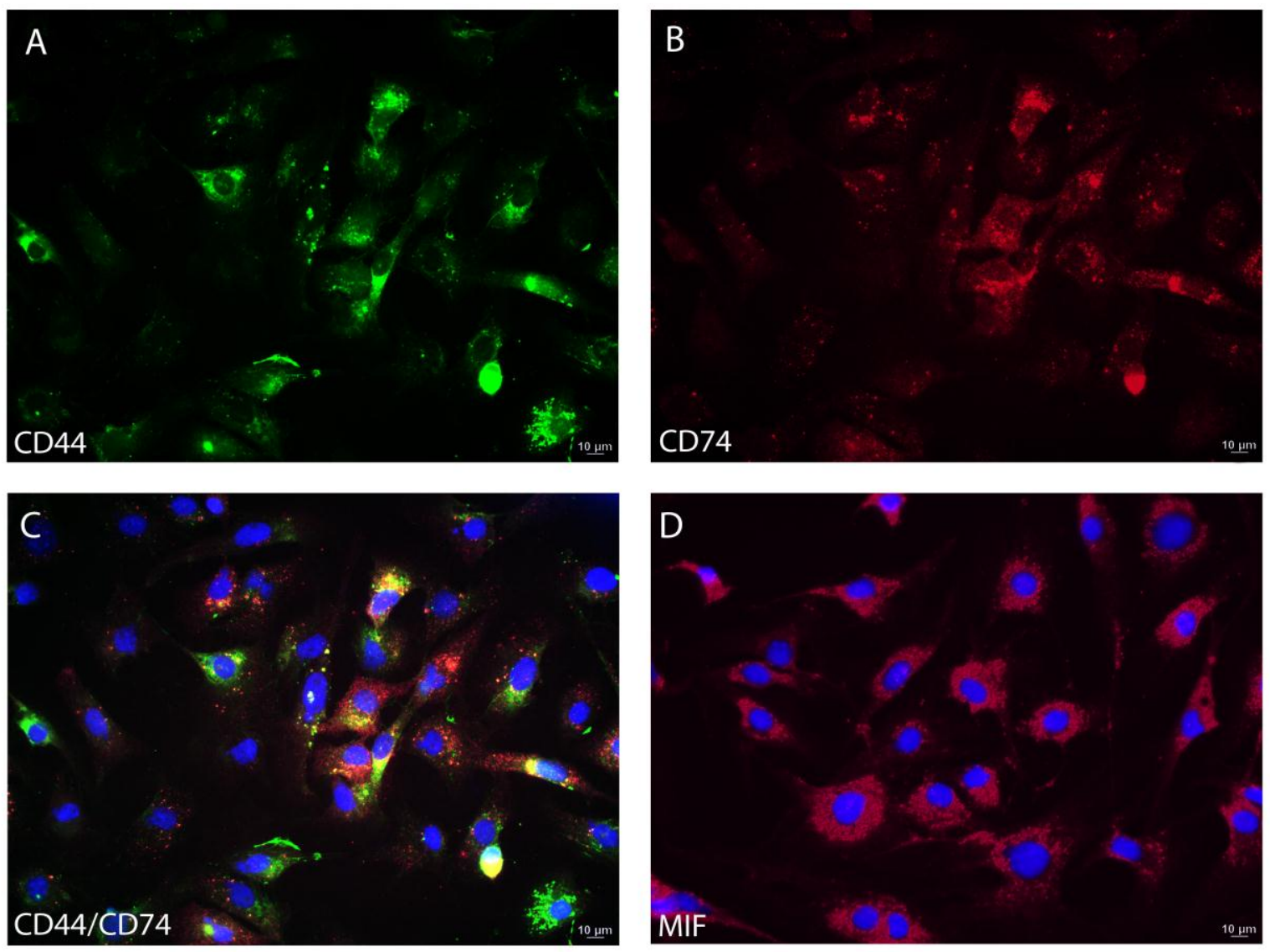

$\mathrm{E}$

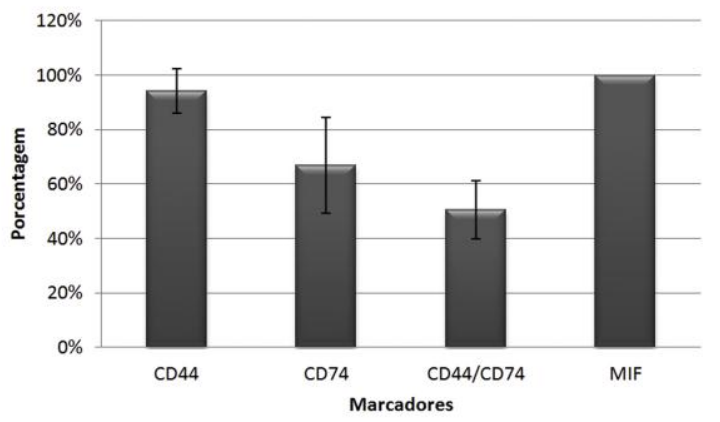

Células deciduais cultivadas por 24 horas foram imunoreativas para o coreceptor CD44 (A) e o receptor CD74 (B). Notar no ensaio de dupla marcação a colocalização do complexo receptor/coreceptor nestas células $(\mathbf{C})$. As células também foram imunoreativas para a citocina MIF (D). Nas figuras C-D, os núcleos foram corados com DAPI. (E) Quantificação das células reativas a cada um dos marcadores analisados (valores médios \pm desvio padrão, $n=3$ ). Notar que $50 \%$ das células foram reativas ao complexo receptor/coreceptor de MIF (CD44/CD74). 
Figura 8 - Determinação da concentração ideal de mrMIF
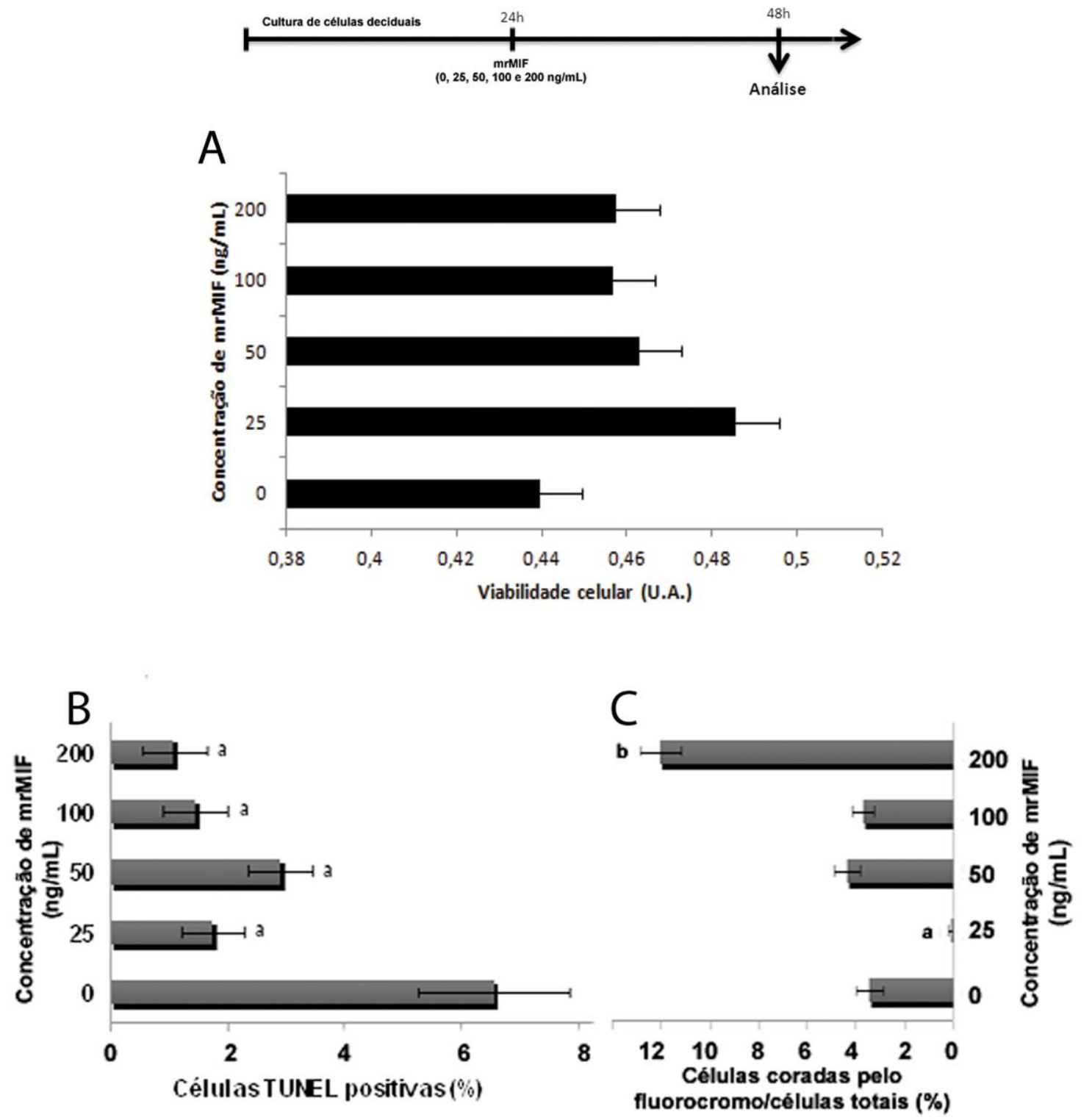

Quantificação das células deciduais viáveis (A, ensaio de MTS) ou em processo de morte celular por apoptose (B, reação de TUNEL) e necrose (C, células coradas por FITC-albumina) após tratamento com concentrações variáveis de $\operatorname{mrMIF}(0,25,50,100$ e $200 \mathrm{ng} / \mathrm{mL})$. Letras diferentes indicam valores estatisticamente diferentes $(p<0,05)$.

\subsection{Sobrevivência das células deciduais após tratamento com $\mathrm{H}_{2} \mathrm{O}_{2}$ na presença de MIF}

A administração de concentrações maiores do que $500 \mu \mathrm{M}$ de $\mathrm{H}_{2} \mathrm{O}_{2}$ às culturas de células deciduais levou a um significativo aumento nas taxas de morte 
por apoptose em relação ao controle $(p<0,05$, Figura $9 A)$. Aumento significativo também foi observado em relação a células necróticas, porém somente em concentrações mais altas da ordem de $2 \mathrm{mM}$ ou mais. Os níveis de grandeza deste aumento foram da ordem de $3 x$ para a concentração de $2 \mathrm{mM}$ e de $9 x$ para a concentração de $4 \mathrm{mM}$ (Figura 9B).

Utilizando-se então a concentração de $2 \mathrm{mM}$ de $\mathrm{H}_{2} \mathrm{O}_{2}$ em ensaios acrescidos de $\mathrm{mrMIF}(25 \mathrm{ng} / \mathrm{mL})$, observa-se nas células cultivadas a redução dos índices apoptóticos $(p<0,05)$, mas não dos necróticos para valores abaixo dos encontrados no controle, que não recebeu nenhum tratamento (Figuras 9C-D).

\subsection{Imunolocalização e expressão das proteínas AKT e $M M_{2}$ nas formas fosforilada e não fosforilada}

Foi imunolocalizado nas células deciduais em todos os grupos experimentais as proteínas $\mathrm{p}$-Akt e $\mathrm{pMDM}_{2}$, em culturas que não receberam qualquer tratamento (controle), culturas tratadas com MIF ( $25 \mathrm{ng} / \mathrm{mL} \mathrm{mrMIF}$ ), em culturas tratadas com os inibidores do PI3K e culturas tratadas com MIF e inibidores do PI3K. A reatividade aos anticorpos mostrou diferenças em relação à quantidade e intensidade de células marcadas (Figuras 10E-H, 11E-H) nos diferentes tratamentos, bem como para sua forma não fosforilada. (Figuras 10A-D, 11A-D). 
Figura 9 - Sobrevivência das células deciduais após tratamento com $\mathrm{H}_{2} \mathrm{O}_{2}$
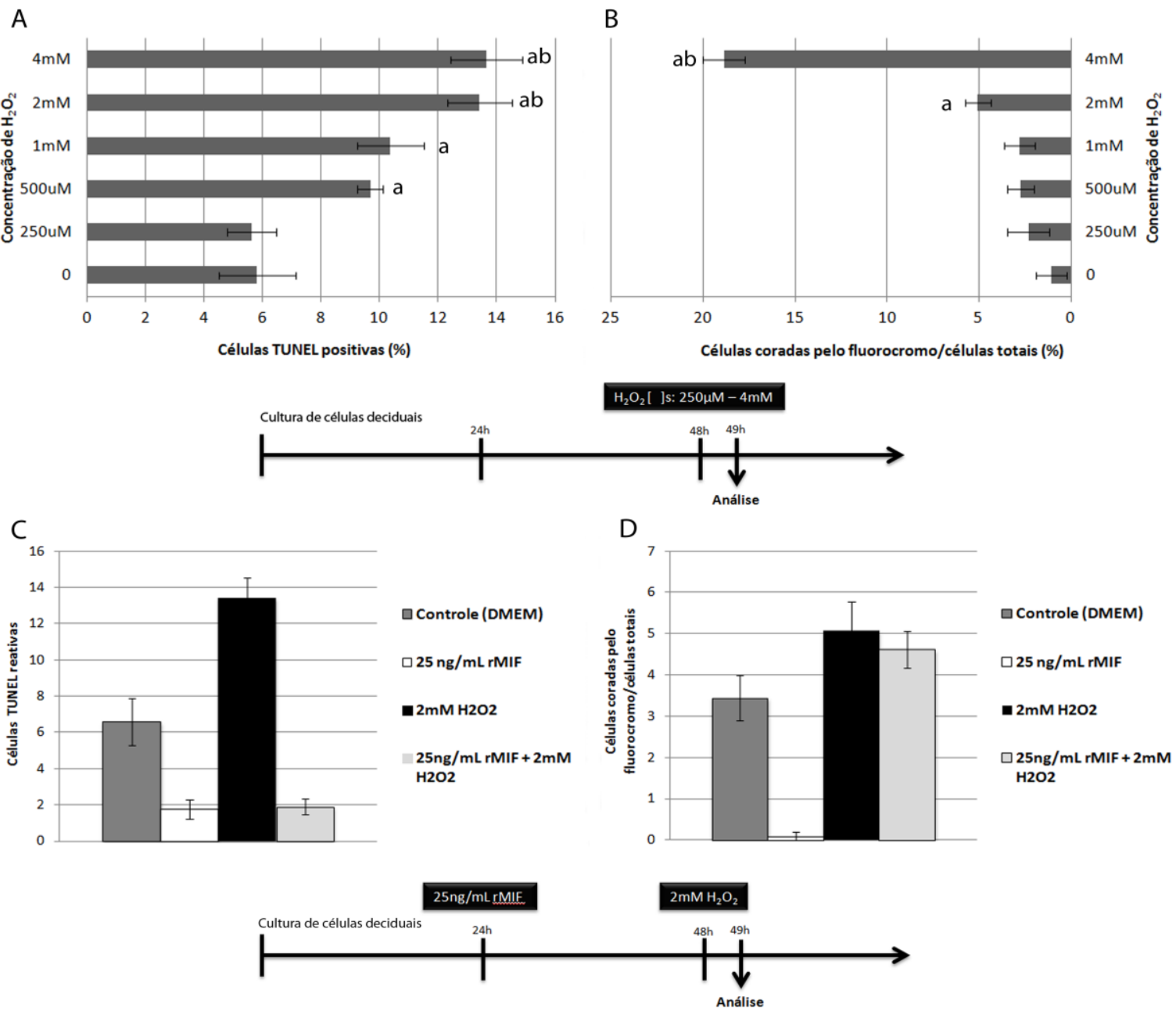

$\mathrm{H}_{2} \mathrm{O}_{2}$ [ ]s: $250 \mu \mathrm{M}-4 \mathrm{mM}$

Células cultivadas e em processo de morte celular por apoptose (A) e necrose (B) foram quantificadas após tratamento com $250 \mu \mathrm{M}, 500 \mu \mathrm{M}, 1 \mathrm{mM}, 2 \mathrm{mM}$ e $4 \mathrm{mM}$ de $\mathrm{H}_{2} \mathrm{O}_{2}$. Células TUNEL reativas e coradas pelo FITC-albumina após tratamento com $25 \mathrm{ng} / \mathrm{mL}$ mrMIF por 24 horas e $2 \mathrm{mM}$ de $\mathrm{H}_{2} \mathrm{O}_{2}$ estão compiladas nos gráficos $\mathbf{C}$ e $\mathbf{D}$, respectivamente. Letras diferentes indicam valores estatisticamente diferentes $(p<0,05)$. 
Figura 10 - Imunolocalização de AKT e pAKT em células deciduais
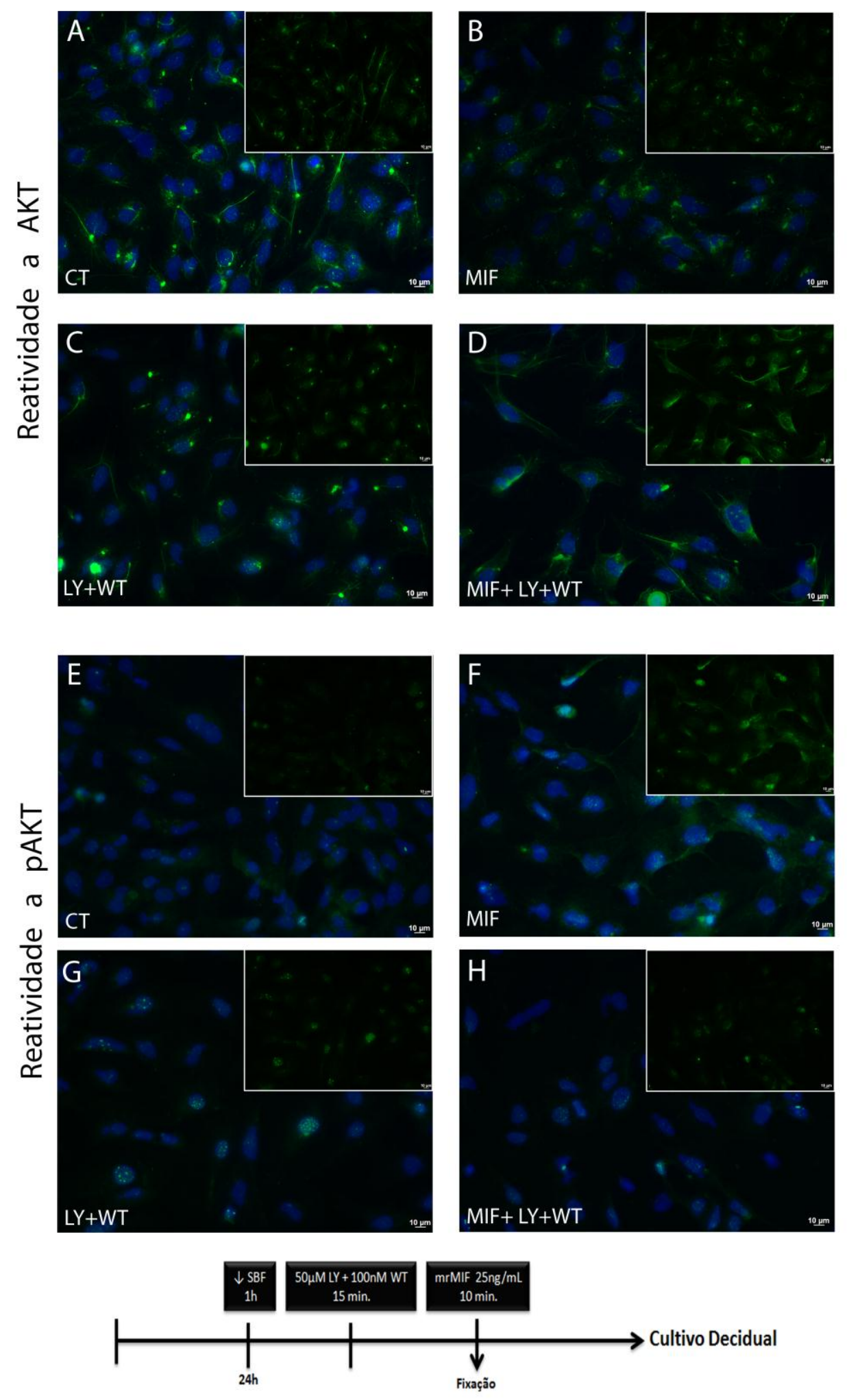

As fotomicrografias mostram respectivamente células deciduais não tratadas e células tratadas com:

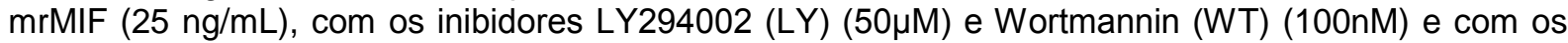
inibidores e MIF (A-D) imunoreativas para AKT. Na mesma sequencia estão representados os tratamentos e imunoreatividade para pAKT (E-H). DAPI cora os núcleos. 
Figura 11 - Imunolocalização de $\mathrm{MDM}_{2}$ e $\mathrm{pMDM}_{2}$ em células deciduais
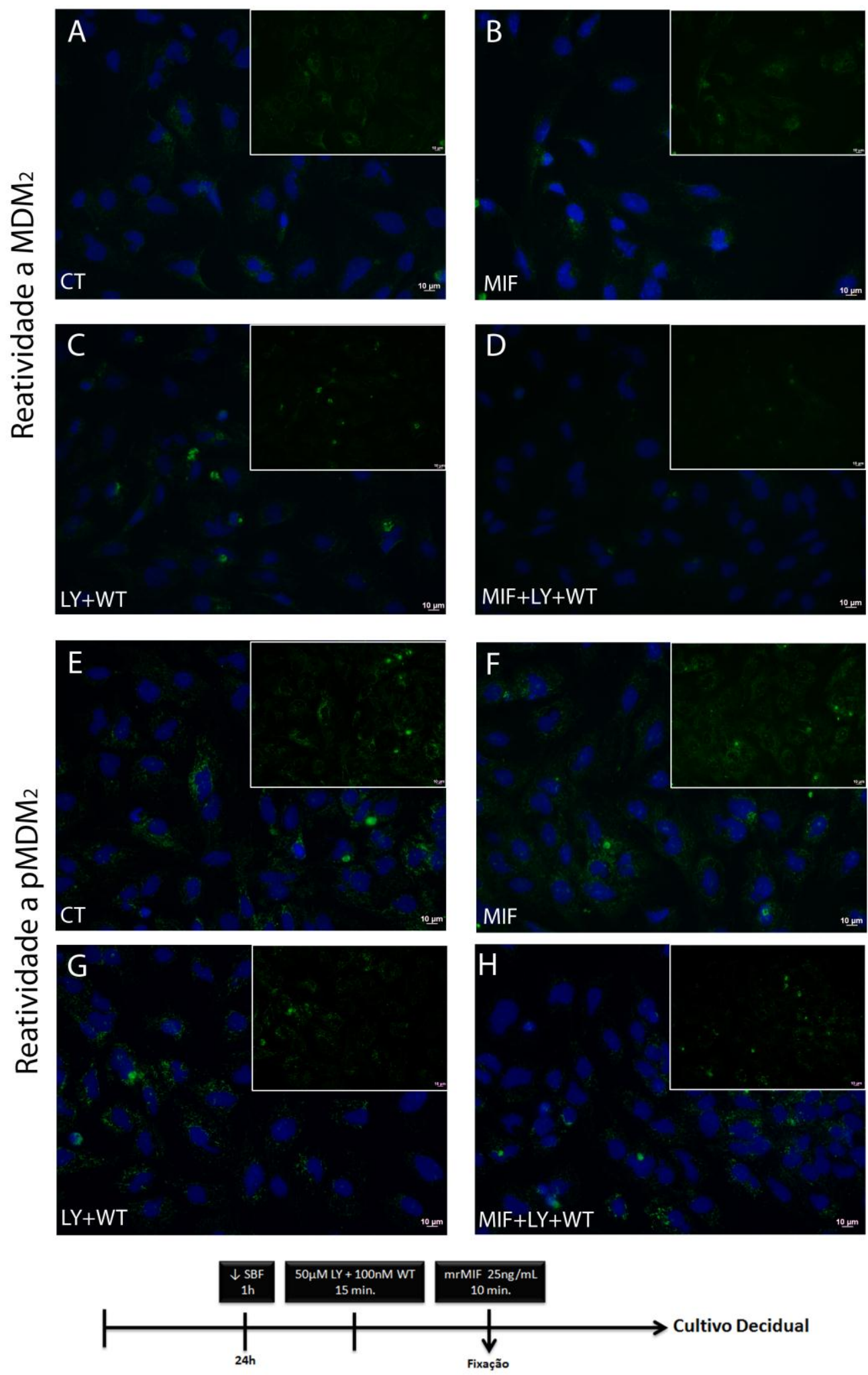

As fotomicrografias mostram respectivamente células deciduais não tratadas e células tratadas com:

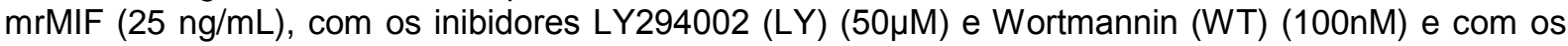
inibidores e MIF (A-D) imunoreativas para $\mathrm{MDM}_{2}$. Na mesma sequência estão representados os tratamentos e imunoreatividade para $\mathrm{pMDM}_{2}(\mathrm{E}-\mathrm{H})$. DAPI cora os núcleos. 


\subsubsection{Western Blotting}

A expressão de AKT e $M_{2} M_{2}$ assim como de suas formas fosforiladas foi analisada. No imunoblotting os anticorpos reconheceram as respectivas bandas (anti-AKT de $60 \mathrm{kDa}$, anti-pAKT de $62 \mathrm{kDa}$, anti-MDM 2 de $55 \mathrm{kDa}$, anti-pMDM 2 de $85 \mathrm{kDa}$, além do controle, $\beta$-actina que reconheceu uma banda de $42 \mathrm{kDa}$ ) que foram quantificadas por densitometria (Figuras 12A,C). Não se observou diferenças significativas entre os grupos para $A K T$ e $M_{2} M_{2}(p \geq 0,05)$. Já para as formas fosforiladas houve um maior índice de expressão nos grupos tratados com mrMIF comparado aos outros grupos, diferença que foi mantida após realizada a razão das respectivas formas fosforiladas sobre as não fosforiladas $(p \leq 0,001$, Figuras $B$ e $D$, Tabela 1). A análise comparativa entre os demais grupos não apresentou diferenças significativas $(p \geq 0,05)$ (Tabela 1). Os valores foram comparados pelo teste ANOVA que foram confirmados pelo Teste Kruskal -Wallis utilizando-se o programa GraphPad InsStat 3.0 (GraphPad Software, San Diego, California, USA), considerados estatisticamente significantes os valores de $p \leq 0,05$.

Tabela 1 - Análise estatística dos resultados da expressão proteica

\begin{tabular}{|c|c|c|c|c|c|c|}
\hline Grupos & AKT & pAKT & pAKT/AKT & $\mathrm{MDM}_{2}$ & $\mathrm{pMDM}_{2}$ & $\mathrm{pMDM}_{2} / \mathrm{MDM}_{2}$ \\
\hline CTxMIF & $p \geq 0,05$ & $p \leq 0,001$ & $p \leq 0,001$ & $p \geq 0,05$ & $p \leq 0,001$ & $p \leq 0,001$ \\
\hline CTxInib. & $p \geq 0,05$ & $p \geq 0,05$ & $p \geq 0,05$ & $p \geq 0,05$ & $p \geq 0,05$ & $p \geq 0,05$ \\
\hline CTxInib.+MIF & $p \geq 0,05$ & $p \geq 0,05$ & $p \geq 0,05$ & $p \geq 0,05$ & $p \geq 0,05$ & $p \geq 0,05$ \\
\hline MIFxInib. & $p \geq 0,05$ & $p \leq 0,001$ & $p \leq 0,001$ & $p \geq 0,05$ & $p \leq 0,001$ & $p \leq 0,001$ \\
\hline MIFxInib.+MIF & $p \geq 0,05$ & $p \leq 0,001$ & $p \leq 0,001$ & $p \geq 0,05$ & $p \leq 0,001$ & $p \leq 0,001$ \\
\hline Inib.xInib.+MIF & $p \geq 0,05$ & $p \geq 0,05$ & $p \geq 0,05$ & $p \geq 0,05$ & $p \geq 0,05$ & $p \geq 0,05$ \\
\hline
\end{tabular}

Diferenças significativas entre os grupos $(p \leq 0,05)$. Teste ANOVA foi utilizado para comparação que foi confirmado pelo Teste Kruskal-Wallis. 
Figura 12 - Quantificação de AKT, pAKT, $\mathrm{MDM}_{2}$ e $\mathrm{pMDM}_{2}$ em células deciduais

A

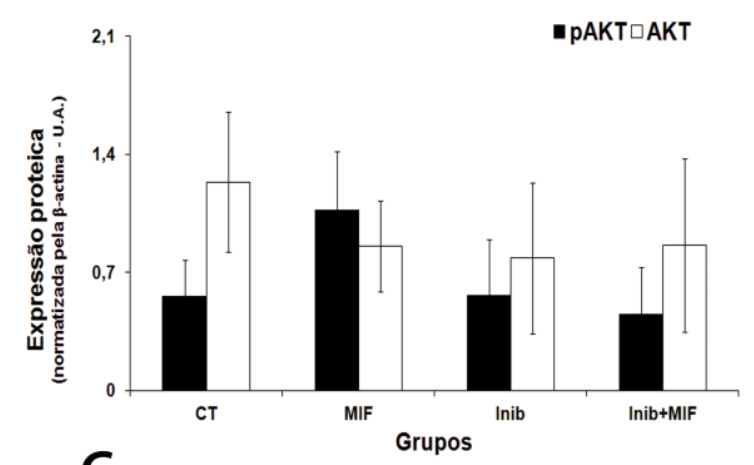

C

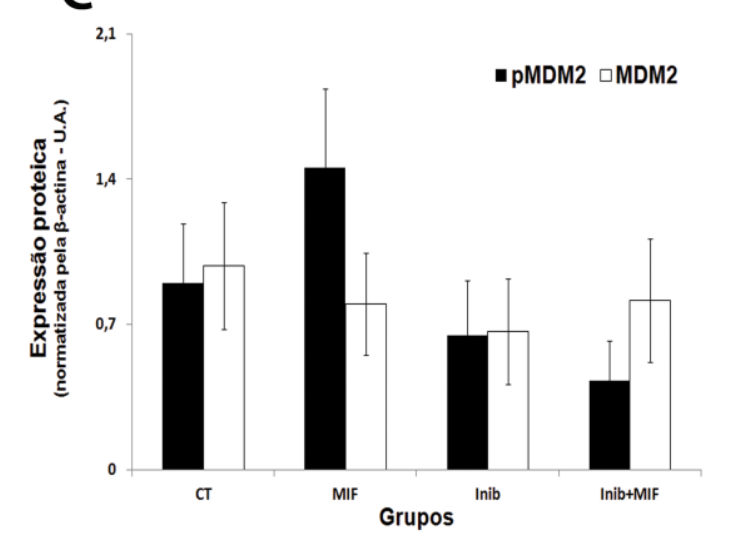

B

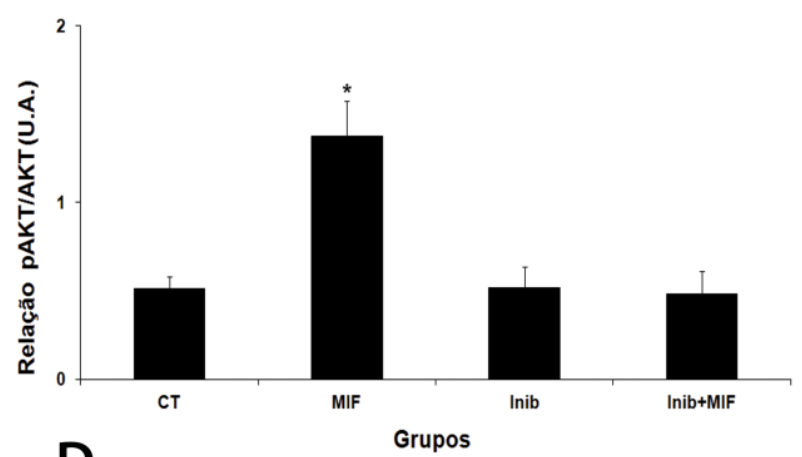

D

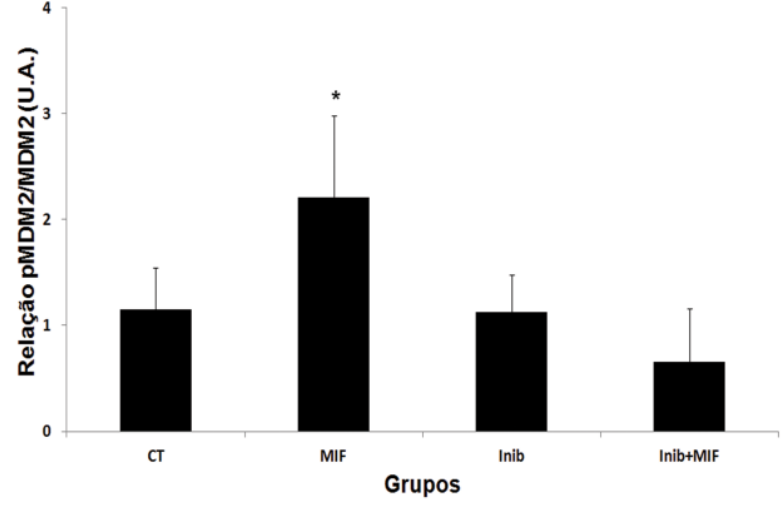

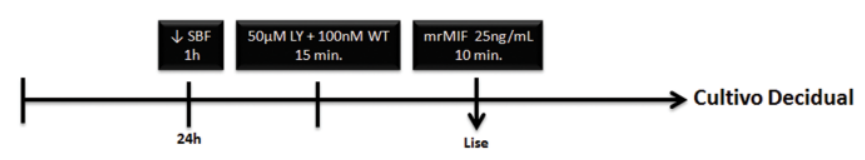

Células deciduais foram cultivadas e tratadas com mrMIF (25ng/mL) (MIF) e/ou com os inibidores (Inib.) LY294002 (50 MM) e Wortmannin (100nM) além do grupo controle que não recebeu tratamento. A expressão de AKT, pAKT (A) e a relação entre a proteína na sua forma fosforilada e não-fosforilada também foi medida e estão compiladas no gráfico B (pAKT/AKT). O mesmo procedimento de quantificação foi realizado para $\mathrm{MDM}_{2}$ e $\mathrm{pMDM}_{2}$ (C) bem como sua relação foi medida e está compilada no gráfico D ( $\left.\mathrm{pMDM}_{2} \mathrm{MDM}_{2}\right)$. 
5 DISCUSSÃO 
Estudos prévios mostraram que muitas das características morfológicas e funcionais das células deciduais são mantidas quando cultivadas (ALMEIDA et al., 2007; BORBELY et al., 2012; KEARNS; LALA, 1983). Em nosso estudo também observamos semelhanças morfológicas com células deciduais in vivo e com as cultivadas e descritas previamente. Após períodos maiores do que $96 \mathrm{~h}$ de cultivo, estas células mostraram ausência de inibição por contato, dispondo-se em camadas estratificadas, hipertrofia predominando sobre proliferação e expressão de marcadores típicos tais como a-2-macroglobulina, vimentina e desmina (ABRAHAMSOHN; ZORN, 1983; BORBELY et al., 2012; GU et al., 1992; TANG; GULLER; GURPIDE, 1993; THOMAS, 1993). A ausência de células expressando filamentos de citoqueratina também favoreceu a idéia de que a técnica de isolamento foi adequada eliminando possíveis contaminantes embrionários ou epiteliais maternos, eventualmente provenientes do epitélio luminal ou glândulas uterinas remanescentes.

Do ponto de vista funcional, estas células não apresentaram proliferação, mas mantiveram-se estáveis em cultivo pelas primeiras $48 \mathrm{~h}$ após o que se observou um evidente declínio no número de células viáveis. Esta característica já havia sido descrita anteriormente (BABIARZ; ROMAGNANO; KURILLA, 1992; BORBELY et al., 2012) e atribuída ao fato de se tratar de uma cultura primária de células terminalmente diferenciadas e com meia-vida in vivo pré-estabelecida. A decídua mesometrial diferencia-se durante a formação da placenta ao redor do $8^{\circ}$ dia de gestação, atinge seu máximo de desenvolvimento ao redor do dia 10 e em seguida regride, desaparecendo por completo antes do pleno estabelecimento da placenta ao redor do dia 14 da prenhez, em camundongos (ABRAHAMSOHN; ZORN, 1993). Correlacionando a fisiologia decidual mesometrial com a sobrevida destas células em cultura, parece que o ciclo de vida destas células se manteve também in vitro, como já visto por outros grupos (BABIARZ; ROMAGNANO; KURILLA, 1992; KEARNS; LALA, 1983).

Para que não houvesse interferência do natural processo de morte das células deciduais com os experimentos delineados neste estudo, optou-se por utilizar células deciduais cultivadas por no máximo $48 \mathrm{~h}$ de modo a não adentrar ao período em que estas células naturalmente degeneram e morrem. 
Assim como in vivo, a expressão de MIF (FARIA et al., 2010) e receptores CD44 e CD74 (MARTUCCI, 2010) foi identificada nas células deciduais. Interessantemente, entretanto, apenas uma parte destas células apresentou colocalização dos receptores, caracterizando-as como potenciais candidatos à ação de MIF, seja de forma autócrina ou parácrina (FARIA et al., 2010). MIF é produzido por leucócitos e macrófagos ativados, populações celulares também encontradas na interface materno-fetal (BAUGH; BUCALA, 2002). Embora muitos estudos mostrem atividade celular mediada pelo MIF demonstrando apenas a expressão de CD74, achados recentes mostraram que a presença de CD44 é fundamental para as respostas biológicas associadas a esta citocina (MEYER-SIEGLER; HUDSON, 1996; SHI et al., 2006).

Digno de destaque neste estudo foi a expressão de MIF imunolocalizado praticamente em todas as células cultivadas. Vários fatores podem ter contribuído para este achado: as técnicas de isolamento utilizadas podem ter privilegiado o isolamento da porção mesometrial já descrita como região de maior produção desta citocina (MARTUCCI, 2010) além das células UNK deciduais em humanos (ARCURI et al., 2006). Ainda, a indução de expressão de MIF pode ter ocorrido em decorrência das condições cultivo de alguma forma reconhecida como fator de estresse funcional ou determinadas pela ausência de fatores inibidores naturais. Lembramos que o MIF é um fator de resposta imediata a condições inflamatórias e de estresse funcional, capaz de desencadear respostas orgânicas de amplo e rápido espectro frente a disfunções teciduais (AMIN et al., 2003; CALANDRA; ROGER, 2003; POLLAK et al., 2005). Neste estudo a expressão de MIF endógeno não foi neutralizada, o que não elimina a possibilidade de esta expressão ter representado um acréscimo acumulativo desta citocina nos efeitos observados in vitro.

Os efeitos da adição de MIF às culturas foram analisados no que diz respeito à indução de morte ou sobrevivência celular nas condições utilizadas, um fator de extrema relevância para as funções deciduais e manutenção da gestação na primeira metade da gestação.

Nossos resultados mostraram que o número de células viáveis aumenta na presença de MIF e que há uma redução significativa das células TUNEL reativas. Estes dados mostram que de alguma forma o MIF interferiu no processo de sobrevivência das células deciduais em cultivo e sugerem a indução de mecanismos específicos associados a esta resposta. Interessantemente, ruptura de membranas 
nas células deciduais que pudessem caracterizar processo necrótico em andamento foi observada em doses bastante altas do MIF recombinante, sugerindo algum grau de toxicidade ou ativação de mecanismos necróticos dose-dependentes. Ao contrário, a dose mais baixa de $25 \mathrm{ng} / \mathrm{mL}$ interferiu no processo de morte celular programada, o que não ocorreu na morte por necrose, que nos induziu a escolher esta concentração para novos testes com indutor de morte.

A ação atenuadora de apoptose exercida pelo MIF foi muito mais evidente quando as culturas foram desafiadas com o peróxido de hidrogênio, uma potente espécie reativa de oxigênio de alta toxicidade celular (YOON et al., 2002). Enquanto que na ausência de MIF o peróxido de hidrogênio aumentou drasticamente o número de células TUNEL reativas, na presença desta citocina houve inibição quase total da ação oxidante desta molécula. O peróxido de hidrogênio é capaz de induzir morte celular pré-programada em inúmeros tecidos e diferentes condições experimentais. O mecanismo pela qual induz apoptose, entretanto, não é bem conhecido, mas, na maioria dos tipos celulares, parece estar relacionado a alterações na permeabilidade da membrana mitocondrial. Esta alteração permitiria a translocação do citocromo $\mathrm{C}$ para o citoplasma com a formação do complexo apoptosomal, ativando caspases mediadoras da apoptose (YOON et al., 2002).

Evidências prévias já haviam relatado a ação de MIF como fator capaz de ativar vias de sobrevivência celular. Em linfócitos $B$ e macrófagos a ligação do MIF ao complexo $\mathrm{CD74/CD44}$ leva à ativação de NF-kB, à entrada da célula no ciclo celular e expressão aumentada de proteínas anti-apoptóticas CD44-dependentes, indicando que o CD74 funciona como um receptor de sobrevivência (GORE et al., 2008; LUE et al., 2007). Ainda, neste contexto, citocinas e fatores de crescimento também já foram descritos como capazes de ativar mecanismos anti-apoptóticos ou de sobrevivência celular associadas à ativação de genes da família $\mathrm{Bcl}-2$ e vias de sinalização mediada por AKT (ARYA; MALLIK; LAKHOTIA, 2007; CORREIA-DASILVA et al., 2005; FAN et al., 2008; RONG; DISTELHORST, 2008) em linfócitos B (GORE et al., 2008; LUE et al., 2007).

Uma vez que houve manutenção da viabilidade das células deciduais na presença de MIF avaliamos também a possível participação da via sinalizadora mediada por AKT neste processo. Na presença de MIF houve um aumento na expressão da forma fosforilada de $\mathrm{AKT}$, bem como de $\mathrm{MDM}_{2}$, substrato dowstream direto de $A K T$, o que mostra que AKT ativado, ativou $\mathrm{MDM}_{2}$. Na relação das formas 
fosforiladas com as formas não fosforiladas de ambas as proteínas, o aumento da expressão do grupo tratado com MIF recombinante foi mantida em relação ao controle, o que não ocorreu nos grupos que receberam inibidores de PI3K, indicando a participação desta via na ativação celular mediada por MIF. A ativação de AKT, no entanto, depende da ativação da quinase fosfoinositol 3 quinase (PI3K) para fosforilar e inativar componentes da maquinaria apoptótica incluindo BAD e caspase 9, ou regular a atividade de fatores de transcrição como o FKHRL1, controlando a expressão de genes críticos para o desencadeamento de morte celular como o Fasligante (ARYA; MALLIK; LAKHOTIA, 2007; CORREIA-DA-SILVA et al., 2005; FAN et al., 2008; RONG; DISTELHORST, 2008) ou ainda, interferir com a atividade de p53 (HUDSON et al., 1999; MAYO; DONNER, 2001; MITCHELL et al., 2002). Neste sentido, o uso de inibidores de PI3K em nossos experimentos, corroborou a hipótese de que a ação protetora do MIF está relacionada à ativação de AKT. Nestes experimentos a associação do MIF aos inibidores não diminuiu os níveis de apoptose que se mantiveram semelhantes aos observados nas culturas não tratadas com MIF e nos ensaios de expressão protéica não houve aumento na expressão das formas fosforiladas nestes grupos que receberam inibidores de PI3K.

No contexto destes resultados, a expressão de MIF na interface materno-fetal pode estar associada a uma ação protetora relevante, na medida em que estas células sobrevivem em um ambiente como o encontrado, por exemplo, na fase pósimplantacional em que abundam interleucinas e citocinas inflamatórias como o IL-1 beta, TNF-alfa e IFN-gama (CALANDRA; ROGER, 2003). Em humanos e em diferentes modelos animais o aumento destas citocinas está relacionado ao aumento dos índices de morte celular e a perdas gestacionais recorrentes (BAINES et al., 1997) e em condições experimentais, à morte das células deciduais (BORBELY et al., 2012). Esta capacidade protetora do MIF pode desta forma, vir a ser um mecanismo de sobrevivência para salvaguardar as células deciduais.

Em suma, a via canônica de sinalização AKT é a principal via responsável pela sobrevivência celular e sua ativação por MIF nas células deciduais pode indicar um papel para esta citocina na homeostase decidual, garantindo a integridade da barreira materno-fetal e, desta forma, a manutenção do privilégio imunológico desta interface imprescindível para o sucesso da gestação (CHAOUAT; DUBANCHET; LEDÉE, 2007; DEKEL et al., 2010; DIMITRIADIS et al., 2005). 
Nossos resultados mostram uma ação direta do MIF sobre as células deciduais com diminuição dos processos de morte celular por apoptose e ativação da via Akt o que, neste contexto, pode significar um papel importante na homeostase decidual. Interessantemente, trabalho prévio (FARIA et al., 2010) mostrou que in vivo são as células trofoblásticas que apresentam maior expressão de MIF durante a fase de pós-implantação o que sugere que MIF pode estar fazendo parte de um diálogo materno-fetal protegendo a decídua de um processo de morte por apoptose prematuro e deletério à gestação. 
6 CONCLUSÕES 
Nossos resultados nos permitiram concluir que in vitro, as células deciduais:

a) expressam o complexo receptor CD44/CD74;

b) apresentam índices baixos de apoptose na presença de MIF;

c) apresentam aumento das proteínas $\mathrm{AKT}$ e $\mathrm{MDM}_{2}$ fosforiladas na presença de MIF sugerindo ativação desta via de sinalização por esta citocina e papel nos processos de controle da sobrevivência da célula decidual. 


\section{REFERÊNCIAS}




\section{REFERÊNCIAS*}

ABRAHAMSOHN, P. A. Ultrastructural study of the mouse antimesometrial decidua. Anat. Embryol., v. 166, n. 2, p. 263-274, 1983.

ABRAHAMSOHN, P. A.; ZORN, T. M. Implantation and decidualization in rodents. J. Exp. Zool., v. 266, n. 6, p. 603-628, 1993.

ADAMSON, S. L.; LU, Y.; WHITELEY, K. J.; HOLMYARD, D.; HEMBERGER, M.; PFARRER, C.; CROSS, J. C. Interactions between trophoblast cells and the maternal and fetal circulation in the mouse placenta. Dev. Biol., v. 250, n. 2, p. 358373, 2002.

ALBERTO-RINCON, M. C.; ZORN, T. M.; ABRAHAMSOHN, P. A. Diameter increase of collagen fibrils of the mouse endometrium during decidualization. Am. J. Anat., v. 186, n. 4, p. 417-429, 1989.

ALESSI, D. R.; JAMES, S. R.; DOWNES, C. P.; HOLMES, A. B.; GAFFNEY, P. R.; REESE, C. B.; COHEN, P. Characterization of a 3-phosphoinositide-dependent protein kinase which phosphorylates and activates protein kinase Balpha. Curr. Biol., v. 7, n. 4, p. 261-269, 1997.

ALMEIDA, A.; CORREIA-DA-SILVA, G.; CEPA, M.; BELL, S. C.; TEIXEIRA, N. A. Synergistic induction of apoptosis in primary rat decidual cells by INF-gamma and TNF. Mol. Reprod. Dev., v. 74, n. 3, p. 371-377, 2007.

AMARANTE-PAFFARO, A.; QUEIROZ, G. S.; CORRÊA, S. T.; SPIRA, B.; BEVILACQUA, E. Phagocytosis as a potential mechanism for microbial defense of mouse placental trophoblast cells. Reproduction, v. 128, n. 2, p. 207-218, 2004.

AMIN, M. A.; VOLPERT, O. V.; WOODS, J. M.; KUMAR, P.; HARLOW, L. A.; KOCH, A. E. Migration inhibitory factor mediates angiogenesis via mitogen-activated protein kinase and phosphatidylinositol kinase. Circ. Res., v. 93, n. 4, p. 321-329, 2003.

AMOROSO, E. C. Endocrinology of pregnancy. Br. Med. Bull., v. 11, n. 2, p. 117125, 1955.

ANDJELKOVIĆ, M.; JAKUBOWICZ, T.; CRON, P.; MING, X. F.; HAN, J. W.; HEMMINGS, B. A. Activation and phosphorylation of a pleckstrin homology domain containing protein kinase (RAC-PK/PKB) promoted by serum and protein phosphatase inhibitors. Proc. Natl. Acad. Sci. U S A., v. 93, n. 12, p. 5699-5704, 1996.

ANSON-CARTWRIGHT, L.; DAWSON, K.; HOLMYARD, D.; FISHER, S. J.; LAZZARINI, R. A.; CROSS, J. C. The glial cells missing-1 protein is essential for branching morphogenesis in the chorioallantoic placenta. Nat. Genet., v. 25, n. 3, p. 311-314, 2000.

*De acordo com: ASSOCIAÇÃO BRASILEIRA DE NORMAS TÉCNICAS. NBR 6023: informação e documentação: referências: elaboração. Rio de Janeiro, 2002. 
APLIN, J. D. Embryo implantation: the molecular mechanism remains elusive. Reprod. Biomed. Online, v. 13, n. 6, p. 833-839, 2006.

ARCARO, A.; WYMANN, M. P. Wortmannin is a potent phosphatidylinositol 3-kinase inhibitor: the role of phosphatidylinositol 3,4,5-trisphosphate in neutrophil responses. Biochem. J., v. 296, n. 2, p. 297-301, 1993.

ARCURI, F.; CINTORINO, M.; VATTI, R.; CARDUCCI, A.; LIBERATORI, S.; PAULESU, L. Expression of macrophage migration inhibitory factor transcript and protein by first-trimester human trophoblasts. Biol. Reprod., v. 60, n. 6, p. 12991303, 1999.

ARCURI, F.; RICCI, C.; IETTA, F.; CINTORINO, M.; TRIPODI, S. A.; CETIN, I.; GARZIA, E.; SCHATZ, F.; KLEMI, P.; SANTOPIETRO, R.; PAULESU, L. Macrophage migration inhibitory factor in the human endometrium: expression and localization during the menstrual cycle and early pregnancy. Biol. Reprod., v. 64, n. 4, p. 1200-1205, 2001.

ARCURI, F.; CINTORINO, M.; CARDUCCI, A.; PAPA, S.; RIPARBELLI, M. G.; MANGIONI, S.; DI BLASIO, A. M.; TOSI, P.; VIGANÒ, P. Human decidual natural killer cells as a source and target of macrophage migration inhibitory factor. Reproduction, v. 131, n. 1, p. 175-182, 2006.

ARCURI, F.; BUCHWALDER, L.; TOTI, P.; CINTORINO, M.; TOSI, P.; LOCKWOOD, C. J.; RYBALOV, B.; SCHATZ, F. Differential regulation of colony stimulating factor 1 and macrophage migration inhibitory factor expression by inflammatory cytokines in term human decidua: implications for macrophage trafficking at the fetal-maternal interface. Biol. Reprod., v. 76, n. 3, p. 433-439, 2007.

ARYA, R.; MALLIK, M.; LAKHOTIA, S. C. Heat shock genes - integrating cell survival and death. J. Biosci., v. 32, n. 3, p. 595-610, 2007.

AUGER, K. R.; CARPENTER, C. L.; CANTLEY, L. C.; VARTICOVSKI, L. Phosphatidylinositol 3-kinase and its novel product, phosphatidylinositol 3phosphate, are present in Saccharomyces cerevisiae. J. Biol. Chem., v. 264, n. 34, p. 20181-20184, 1989.

BABIARZ, B. S.; ROMAGNANO, L. C.; KURILLA, G. M. Interaction of mouse ectoplacental cone trophoblast and uterine decidua in vitro. In Vitro Cell Dev. Biol., v. 28A, n. 7-8, p. 500-508, 1992.

BAINES, M. G.; DUCLO, A. J.; ANTECKA, E.; HADDAD, E. K. Decidual infiltration and activation of macrophages leads to early embryo loss. Am. J. Immunol., v. 37, p. 471-477, 1997.

BAUGH, J. A.; BUCALA, R. Macrophage migration inhibitory factor. Crit. Care Med., v. 30, n. 1, p. S27-35, 2002. Suppl. 
BELLACOSA, A.; TESTA, J. R.; STAAL, S. P.; TSICHLIS, P. N. A retroviral oncogene, akt, encoding a serine-threonine kinase containing an SH2-like region. Science, v. 254, n. 5029, p. 274-277, 1991.

BERNDT, K.; KIM, M.; MEINHARDT, A.; KLUG, J. Macrophage migration inhibitory factor does not modulate co-activation of androgen receptor by Jab1/CSN5. Mol. Cell Biochem., v. 307, n. 1-2, p. 265-271, 2008.

BERNHAGEN, J.; CALANDRA, T.; MITCHELL, R. A.; MARTIN, S. B.; TRACEY, K. J.; VOELTER, W.; MANOGUE, K. R.; CERAMI, A.; BUCALA, R. MIF is a pituitaryderived cytokine that potentiates lethal endotoxaemia. Nature, v. 365, p. 756-759, 1993.

BERNHAGEN, J.; KROHN, R.; LUE, H.; GREGORY, J. L.; ZERNECKE, A.; KOENEN, R. R.; DEWOR, M.; GEORGIEV, I.; SCHOBER, A.; LENG, L.; KOOISTRA, T.; FINGERLE-ROWSON, G.; GHEZZI, P.; KLEEMANN, R.; MCCOLL, S. R.; BUCALA, R.; HICKEY, M. J.; WEBER, C. MIF is a noncognate ligand of CXC chemokine receptors in inflammatory and atherogenic cell recruitment. Nat. Med., v. 13, n. 5, p. 587-596, 2007.

BESWICK, E. J.; REYES, V. E. CD74 in antigen presentation, inflammation, and cancers of the gastrointestinal tract. World J. Gastroenterol., v. 15, n. 23, p. 28552861, 2009.

BEVILACQUA, E. M.; ABRAHAMSOHN, P. A. Trophoblast invasion during implantation of the mouse embryo. Arch. Biol. Med. Exp., v. 22, n. 2, p. 107-118, 1989.

BIJOVSKY, A. T.; ZORN, T. M.; ABRAHAMSOHN, P. A. Remodeling of the mouse endometrial stroma during the preimplantation period. Acta Anat., v. 144, n. 3, p. 231-234, 1992.

BLOOM, B. R.; BENNETT, B. Mechanism of a reaction in vitro associated with delayed-type hypersensitivity. Science, v. 153, n. 731, p. 80-82, 1966.

BORBELY, A. U.; FONTENELE-NETO, J. D.; VIDSIUNAS, A. K.; GOMES, S. Z.; HOSHIDA, M. S.; DE OLIVEIRA, S. F.; BEVILACQUA, E. Ectoplacental Cone Induces Resistance to Apoptosis in High Doses of Interferon (IFN)- $\mathrm{Y}$-Treated Decidual Cells. Am. J. Reprod. Immunol., v. 67, n. 1, p. 73-83, 2012.

BOZZA, M.; SATOSKAR, A. R.; LIN, G.; LU, B.; HUMBLES, A. A.; GERARD, C.; DAVID, J. R. Targeted disruption of migration inhibitory factor gene reveals its critical role in sepsis. J. Exp. Med., v. 189, p. 341-346, 1999.

BRAZIL, D. P.; HEMMINGS, B. A. Ten years of protein kinase B signalling: a hard Akt to follow. Trends Biochem. Sci., v. 26, n. 11, p. 657-664, 2001.

CALANDRA, T.; BERNHAGEN, J.; MITCHELL, A.; BUCALA, R. The macrophage is an important and previously unrecognized source of macrophage migration inhibitory factor. J. Exp. Med., v. 179, p. 1895-1902, 1994. 
CALANDRA, T.; BERNHAGEN, J.; METZ, C. N.; SPIEGEL, L. A.; BACHER, M.; DONNELLY, T.; CERAMI, A.; BUCALA, R. MIF as a glucocorticoid-indeced modulator of cytokine production. Nature, v. 377, p. 68-71, 1995.

CALANDRA, T.; ROGER, T. Macrophage migration inhibitory factor: a regulator of innate immunity. Nat. Rev. Immunol., v. 3, n. 10, p. 791-800, 2003.

CAN, A.; TEKELIOGLU, M.; BALTACI, A. Expression of desmin and vimentin intermediate filaments in human decidual cells during first trimester pregnancy. Placenta, v. 16, n. 3, p. 261-275, 1995.

CARDAROPOLI, S.; PAULESU, L.; ROMAGNOLI, R.; IETTA, F.; MARZIONI, D.; CASTELLUCCI, M.; ROLFO, A.; VASARIO, E.; PICCOLI, E.; TODROS, T. Macrophage migration inhibitory factor in fetoplacental tissues from preeclamptic pregnancies with or without fetal growth restriction. Clin. Dev. Immunol., 2012. Epub 2011 Oct 4.

CARVALHO, J. V.; ALVES, C. M.; CARDOSO, M. R.; MOTA, C. M.; BARBOSA, B. F.; FERRO, E. A.; SILVA, N. M.; MINEO, T. W.; MINEO, J. R.; SILVA, D. A. Differential susceptibility of human trophoblastic (BeWo) and uterine cervical (HeLa) cells to Neospora caninum infection. Int J Parasitol., v. 40, n. 14, p. 1629-1637, 2010.

CHAMPION, H.; INNES, B. A.; ROBSON, S. C.; LASH, G. E.; BULMER, J. N. Effects of interleukin-6 on extravillous trophoblast invasion in early human pregnancy. Mol. Hum. Reprod., v. 18, n. 8, p. 391-400, 2012.

CHAOUAT, G.; DUBANCHET, S.; LEDÉE, N. Cytokines: Important for implantation? J. Assist. Reprod. Genet., v. 24, n. 11, p. 491-505, 2007.

COFFER, P. J.; WOODGETT, J. R. Molecular cloning and characterisation of a novel putative protein-serine kinase related to the cAMP-dependent and protein kinase $\mathrm{C}$ families. Eur. J. Biochem., v. 201, n. 2, p. 475-481, 1991.

COHEN, M.; BISCHOF, P. Factors regulating trophoblast invasion. Gynecol Obstet Invest., v. 64, n. 3, p. 126-130, 2007.

CORREIA-DA-SILVA, G.; BELL, S. C.; PRINGLE, J. H.; TEIXEIRA, N. A. Patterns of expression of $\mathrm{Bax}, \mathrm{Bcl}-2$ and $\mathrm{Bcl}-\mathrm{x}(\mathrm{L})$ in the implantation site in rat during pregnancy. Placenta, v. 26, n. 10, p. 796-806, 2005.

CROSS, J. C. How to make a placenta: mechanisms of trophoblast cell differentiation in mice - a review. Placenta, v. 26, p. S 3-9, 2005. Suppl A.

CROSS, J. C.; HEMBERGER, M.; LU, Y.; NOZAKI, T.; WHITELEY, K.; MASUTANI, M.; ADAMSON, S. L. Trophoblast functions, angiogenesis and remodeling of the maternal vasculature in the placenta. Mol. Cell Endocrinol., n. 187, n. 1-2, p. 207212, 2002. 
CROY, B. A.; HE, H.; ESADEG, S.; WEI, Q.; MCCARTNEY, D.; ZHANG, J.; BORZYCHOWSKI, A.; ASHKAR, A. A.; BLACK, G. P.; EVANS, S. S.; CHANTAKRU, S.; VAN DEN HEUVEL, M.; PAFFARO, V. A. JR.; YAMADA, A. T. Uterine natural killer cells: insights into their cellular and molecular biology from mouse modelling. Reproduction, v. 126, n. 2, p. 149-160, 2003.

DAHL, M.; HVIID, T. V. Human leucocyte antigen class lb molecules in pregnancy success and early pregnancy loss. Hum. Reprod. Update, v. 18, n. 1, p. 92-109, 2012.

DE OLIVEIRA GOMES, A.; DE OLIVEIRA SILVA, D. A.; SILVA, N. M.; DE FREITAS BARBOSA, B.; FRANCO, P. S.; ANGELONI, M. B.; FERMINO, M. L.; ROQUEBARREIRA, M. C.; BECHI, N.; PAULESU, L. R.; DOS SANTOS, M. C.; MINEO, J. R.; FERRO, E. A. Effect of macrophage migration inhibitory factor (MIF) in human placental explants infected with Toxoplasma gondii depends on gestational age. Am. J. Pathol., v. 178, n. 6, p. 2792-2801, 2011.

DEKEL, N.; GNAINSKY, Y.; GRANOT, I.; MOR, G. Inflammation and implantation. Am. J. Reprod. Immunol., v. 63, n. 1, p. 17-21, 2010.

DIMITRIADIS, E.; WHITE, C. A.; JONES, R. L.; SALAMONSEN, L. A. Cytokines, chemokines and growth factors in endometrium related to implantation. Hum. Reprod., v. 11, n. 6, p. 613-630, 2005.

DONNELLY, S. C.; HASLETT, C.; REID, P. T.; GRANT, I. S.; WALLACE, W. A.; METZ, C. N.; BRUCE, L. J.; BUCALA, R. Regulatory role for macrophage migration inhibitory factor in acute respiratory distress syndrome. Nat. Med., v. 3, p. 320-323, 1997.

ENDERS, A. C.; SCHLAFKE, S. Comparative aspects of blastocyst-endometrial interactions at implantation. Ciba Found Symp., v. 64, p. 3-32, 1978.

ENGELMAN, J. A.; LUO, J.; CANTLEY, L. C. The evolution of phosphatidylinositol 3kinases as regulators of growth and metabolism. Nat. Rev. Genet., v. 7, n. 8, p. 606619, 2006.

ENTRICAN, G. Immune regulation during pregnancy and host-pathogen interactions in infectious abortion. J. Comp. Pathol., v. 126, n. 2-3, p. 79-94, 2002.

FAN, Y.; DUTTA, J.; GUPTA, N.; FAN, G.; GÉLINAS, C. Regulation of programmed cell death by NF-kappaB and its role in tumorigenesis and therapy. Adv. Exp. Med. Biol., v. 615, p. 223-250, 2008.

FARIA, M. R.; HOSHIDA, M. S.; FERRO, E. A.; IETTA, F.; PAULESU, L.; BEVILACQUA, E. Spatiotemporal patterns of macrophage migration inhibitory factor (Mif) expression in the mouse placenta. Reprod. Biol. Endocrinol., v. 4, p. 1-9, 2010

FAYARD, E.; TINTIGNAC, L. A.; BAUDRY, A.; HEMMINGS, B. A. Protein kinase B/Akt at a glance. J. Cell Sci., v. 118, n. 24, p. 5675-5678, 2005. 
FERRO, E. A.; BEVILACQUA, E. Trophoblastic invasion of the uterine epithelium in Calomys callosus (Rodentia, Cricetidae). J. Morphol., v. 221, n. 2, p. 139-152, 1994.

FERRO, E. A.; MINEO, J. R.; IETTA, F.; BECHI, N.; ROMAGNOLI, R.; SILVA, D. A.; SORDA, G.; BEVILACQUA, E.; PAULESU, L. R. Macrophage migration inhibitory factor is up-regulated in human first-trimester placenta stimulated by soluble antigen of Toxoplasma gondii, resulting in increased monocyte adhesion on villous explants. Am. J. Pathol., v. 172, n. 1, p. 50-58, 2008.

FINN, C. A. The biology of decidual cells. Adv. Reprod. Physiol., v. 5, p. 1-26, 1971.

FLASTER, H.; BERNHAGEN, J.; CALANDRA, T.; BUCALA, R. The macrophage migration inhibitory factor-glucocorticoid dyad: regulation of inflammation and immunity. Mol. Endocrinol., v. 21, n. 6, p. 1267-1280, 2007.

FRANCO, P. S.; GOMES, A. O.; BARBOSA, B. F.; ANGELONI, M. B.; SILVA, N. M.; TEIXEIRA-CARVALHO, A.; MARTINS-FILHO, O. A.; SILVA, D. A.; MINEO, J. R.; FERRO, E. A. Azithromycin and spiramycin induce anti-inflammatory response in human trophoblastic (BeWo) cells infected by Toxoplasma gondii but are able to control infection. Placenta, v. 32, n. 11, p. 838-844, 2011.

GLASSER, S. R.; LAMPELO, S.; MUNIR, M. I.; JULIAN, J. Expression of desmin, laminin and fibronectin during in situ differentiation (decidualization) of rat uterine stromal cells. Differentiation, v. 35, n. 2, p. 132-142, 1987.

GLASSER, S. R.; JULIAN, J. Intermediate filament protein as a marker of uterine stromal cell decidualization. Biol. Reprod., v. 35, n. 2, p. 463-474, 1986.

GORE, Y.; STARLETS, D.; MAHARSHAK, N.; BECKER-HERMAN, S.; KANEYUKI, U.; LENG, L.; BUCALA, R.; SHACHAR, I. Macrophage Migration Inhibitory Factor Induces B Cell Survival by Activation of a CD74-CD44 Receptor Complex. J. Biol. Chem., v. 283, n. 5, p. 2784-2792, 2008.

GU, Y.; JAYATILAK, P. G.; PARMER, T. G.; GAULDIE, J.; FEY, G. H.; GIBORI, G. Alpha 2-macroglobulin expression in the mesometrial decidua and its regulation by decidual luteotropin and prolactin. Endocrinology, v. 131, n. 3, p. 1321-1328, 1992.

GUILBERT, L.; ROBERTSON, S. A.; WEGMANN, T. G. The trophoblast as an integral component of a macrophage-cytokine network. Immunol. Cell Biol., v. 71, n. 1, p. 49-57, 1993.

GUILIANO, D. B.; HALL, N.; JONES, S. J. M.; CLARK, L. N.; CORTON, C. H.; BARRELL, B. G.; BLAXTER, M. L. Conservation of long-range sunteny and microsynteny between the genomes of two distantly related nematodes. Genome Biology, v. 3, p. 1-14, 2002.

GUIMOND, M.; WANG, B.; CROY, B. A. Immune competence involving the natural killer cell lineage promotes placental growth. Placenta, v. 20, n. 5-6, p. 441-450, 1999. 
GREMLICH, S.; CHANSON, A.; URNER, F.; SENN, A.; REYMONDIN, D.; DAMNON, F.; ROTH-KLEINER, M.; WITKIN, S. S.; GERMOND, M.; GERBER S. LIF and sIL-2R plasma concentrations in IVF patients on the day of embryo transfer: predictive markers of IVF outcome. J. Reprod. Immunol. v. 94, n. 2, p. 175-182, 2012.

HONDA, A.; ABE, R.; MAKINO, T.; NORISUGI, O.; FUJITA, Y.; WATANABE, H.; NISHIHIRA, J.; IWAKURA, Y.; YAMAGISHI, S.; SHIMIZU, H.; SHIMIZU, T. Interleukin-1b and macrophage migration inhibitory factor (MIF) in dermal fibroblasts mediate UVA-induced matrix metalloproteinase-1 expression. J. Dermatol. Sc., v. 49, p. 63-72, 2008.

HUDSON, J. D.; SHOAIBI, M. A.; MAESTRO, R.; CARNERO, A.; HANNON, G. J.; BEACH, D. H. A proinflammatory cytokine inhibits p53 tumor suppressor activity. J. Exp. Med., v. 190, n. 10, p. 1375-1382, 1999.

IETTA, F.; TODROS, T.; TICCONI, C.; PICCOLI, E.; ZICARI, A.; PICCIONE, E.; PAULESU, L. Macrophage migration inhibitory factor in human pregnancy and labor. Am. J. Reprod. Immunol., v. 48, p. 404-409, 2002.

IETTA, F.; WU, Y.; ROMAGNOLI, R.; SOLEYMANLOU, N.; ORSINI, B.; ZAMUDIO, S.; PAULESU, L.; CANIGGIA, I. Oxygen regulation of macrophage migration inhibitory factor in human placenta. Am. J. Physiol. Endocrinol. Metab., v. 292, n. 1, p. E272-280, 2007.

JAWORSKI, D. C.; JASINSKAS, A.; METZ, C. N.; BUCALA, R.; BARBOUR, A. G. Identification and characterization of a homologue of the pro-inflammatory cytokine Macrophage Migration Inhibitory Factor in the tick, Amblyomma americanum. Insetct Mol. Biol., v. 10, n.4, p. 323-331, 2001.

KATS, R.; AL-AKOUM, M.; GUAY, S.; METZ, C.; AKOUM, A. Cycle dependent expression of macrophage migration inhibitory factor in the human endometrium. Human Reprod., v. 20, p. 3518-3525, 2005.

KEARNS, M.; LALA, P. K. Life history of decidual cells: a review. Am. J. Reprod. Immunol., v. 3, n. 2, p. 78-82, 1983.

KLEINFELD, R. G.; MORROW, H.; DEFEO, V. J. Intercellular junctions between decidual cells in the growing deciduoma of the pseudopregnant rat uterus. Biol. Reprod., v.15, n. 5, p. 593-603, 1976.

KUMAR, C. C.; MADISON, V. AKT crystal structure and AKT-specific inhibitors. Oncogene, v. 24, n. 50, p. 7493-7501, 2005.

LAN, H. Y. Role of macrophage migration inhibition factor in kidney disease. Nephron Exp. Nephrol., v. 109, n. 3, p 79-83, 2008.

LASH, G. E.; OTUN, H. A.; INNES, B. A.; BULMER, J. N.; SEARLE, R. F.; ROBSON, S. C. Inhibition of trophoblast cell invasion by TGFB1, 2, and 3 is associated with a decrease in active proteases. Biol. Reprod., v. 73, n. 2, p. 374-381, 2005. 
LASH, G. E.; SCHIESSL, B.; KIRKLEY, M.; INNES, B. A.; COOPER, A.; SEARLE, R. F.; ROBSON, S. C.; BULMER, J. N. Expression of angiogenic growth factors by uterine natural killer cells during early pregnancy. J. Leukoc. Biol., v. 80, n. 3, p. 572-580, 2006.

LASH, G. E.; ROBSON, S. C.; BULMER, J. N. Review: Functional role of uterine natural killer (uNK) cells in human early pregnancy decidua. Placenta, v. 31 p. S8792, 2010.

LENG, L.; METZ, C. N.; FANG, Y.; XU, J.; DONNELLY, S.; BAUGH, J.; DELOHERY, T.; CHEN, Y.; MITCHELL, R. A.; BUCALA, R. MIF signal transduction initiated by binding to CD74. J. Exp. Med., v. 197, p. 1467-1476, 2003.

LIN, H.; MOSMANN, T. R.; GUILBERT, L.; TUNTIPOPIPAT, S.; WEGMANN, T. G. Synthesis of $T$ helper 2-type cytokines at the maternal-fetal interface. J. Immunol., v. 151, n. 9, p. 4562-4573, 1993.

LUE, $H_{\text {.; }}$ KLEEMANN, R.; CALANDRA, T.; ROGER, T.; BERNHAGEN, J. Macrophage migration inhibitory factor (MIF): mechanisms of action and role in disease. Microbes Infect., v. 4, p. 449-460, 2002.

LUE, H.; KAPURNIOTU, A.; FINGERLE-ROWSON, G.; ROGER, T.; LENG, L.; THIELE, M.; CALANDRA, T.; BUCALA, R.; BERNHAGEN, J. Rapid and transient activation of the ERK MAPK signalling pathway by macrophage migration inhibitory factor (MIF) and dependence on JAB1/CSN5 and Src kinase activity. Cell Signal, v. 18 , p. 688-703, 2006.

LUE, H.; THIELE, M.; FRANZ, J.; DAHL, E.; SPECKGENS, S.; LENG, L.; FINGERLE-ROWSON, G.; BUCALA, R.; LÜSCHER, B.; BERNHAGEN, J. Macrophage migration inhibitory factor (MIF) promotes cell survival by activation of the Akt pathway and role for CSN5/JAB1 in the control of autocrine MIF activity. Oncogene, v. 26, n. 35, p. 5046-5059, 2007.

MÄKIKALLIO, K.; KAUKOLA, T.; TUIMALA, J. F.; KINGSMORE, S.; HALLMAN, M.; OJANIEMI, M. Umbilical artery chemokine CCL16 is associated with preterm preeclampsia and fetal growth restriction. Cytokine, 2012. In press.

MANNING, B. D.; CANTLEY, L. C. AKT/PKB signaling: navigating downstream. Cell, v. 129, n. 7, p. 1261-1274, 2007.

MARTUCCI, M. F. Expressão do complexo receptor CD74-CD44 para o fator de inibição da migração de macrófagos (MIF) na interface materno placentária em camundongos. 2010. 75 p. Tese de Mestrado em Biologia Celular e Tecidual. Instituto de Ciências Biomédicas, Universidade de São Paulo, São Paulo.

MATTHIESEN, L.; KALKUNTE, S.; SHARMA, S. Multiple pregnancy failures: an immunological paradigm. Am. J. Reprod. Immunol., v. 67, n. 4, p. 334-340, 2012. 
MAYO, L. D.; DONNER, D. B. A phosphatidylinositol 3-kinase/Akt pathway promotes translocation of Mdm2 from the cytoplasm to the nucleus. PNAS, v. 98, n. 25, p. 11598-11603, 2001.

MEYER-SIEGLER, K.; HUDSON, P. B. Enhanced expression of macrophage migration inhibitory factor in prostatic adenocarcinoma metastases. Urology, v. 48, n. 3 p. 448-452, 1996.

MEYER-SIEGLER, K. L.; LEIFHEIT, E. C.; VERA, P. L. Inhibition of macrophage migration inhibitory factor decreases proliferation and cytokine expression in bladder cancer cells. BMC Cancer, v.12, p. 4:34, 2004.

MITCHELL, R. A.; LIAO, H.; CHESNEY, J.; FINGERLE-ROWSON, G.; BAUGH, J.; DAVID, J.; BUCALA, R. Macrophage migration inhibitory factor (MIF) sustains macrophage proinflammatory function by inhibiting p53: regulatory role in the innate immune response. Proc. Natl. Acad. Sci. U S A., v. 99, n. 1, p. 345-350, 2002.

MITCHELL, R. A. Mechanisms and effectors of MIF-dependent promotion of tumourigenesis. Cell Signal, v. 16, n. 1, p. 13-19, 2004.

MOSSMAN, H. W. Comparative morphogenesis of the fetal membranes and accessory uterine structures. Contr. Embryol. Carneg. Inst., v. 26, p. 133-246, 1937.

NANCY, P.; TAGLIANI, E.; TAY, C. S.; ASP, P.; LEVY, D. E.; ERLEBACHER, A. Chemokine gene silencing in decidual stromal cells limits $T$ cell access to the maternal-fetal interface. Science, v. 336, n. 6086, p. 1317-1321, 2012.

NAUJOKAS, M. F.; MORIN, M.; ANDERSON, M. S.; PETERSON, M.; MILLER, J. The chondroitin sulfate form of invariant chain can enhance stimulation of $T$ cell responses through interaction with CD44. Cell, v. 74, p. 257-266, 1993.

NISHIHIRA, J.; KOYAMA, Y.; MIZUE,' Y. Identification of Macrophage Migration Inhibitory Factor (MIF) in human vascular endothelial cells and its inductio by lipopolysacharide. Cytokine, v. 10, n. 3, p. 199-205, 1998.

OLIVEIRA, S. F.; GRECA, C. P.; ABRAHAMSOHN, P. A.; REIS, M. G.; ZORN, T. M. Organization of desmin-containing intermediate filaments during differentiation of mouse decidual cells. Histochem. Cell Biol., v. 113, n. 4, p. 319-327, 2000.

OLIVEIRA, S. F.; ABRAHAMSOHN, P. A.; NAGATA, T.; ZORN, T. M. Incorporation of $3 \mathrm{H}$-amino acids by endometrial stromal cells during decidualization in the mouse. A radioautographical study. Cell Mol. Biol., v. 41, n 1, p. 107-116, 1995.

ORESHKOVA, T.; DIMITROV, R.; MOURDJEVA, M. A cross-talk of decidual stromal cells, trophoblast, and immune cells: a prerequisite for the success of pregnancy. Am. J. Reprod. Immunol., 2012. In press. 
PAULESU, L.; CATENI, C.; ROMAGNOLI, R.; IETTA, F.; DANTZER, V. Variation in macrophage-migration-inhibitory-factor immunoreactivity during porcine gestation. Biol. Reprod., v. 72, n. 4, p. 949-953, 2005.

PASTRANA, D. V.; RAGHAVAN, N.; FITZGERALD, P.; EISINGER, S. W.; METZ, C.; BUCALA, R.; SCHLEIMER, R. P.; BICKEL, C.; SCOTT, A. L. Filarial nematode parasites secrete a homologue of the human cytokine macrophage migration inhibitory factor. Infect. Immun., v. 66, p. 5955-5963, 1998.

PAULESU, L.; CATENI, C.; ROMAGNOLI, R.; IETTA, F.; DANTZER, V. Variation in macrophage-migration-inhibitory-factor immunoreactivity during. porcine gestation. Biol. Reprod., v. 72, n. 4, p. 949-953, 2005.

PAULESU, L.; BHATTACHARJEE, J.; BECHI, N.; ROMAGNOLI, R.; JANTRA, S.; IETTA, F. Pro-inflammatory cytokines in animal and human gestation. Curr. Pharm. Des., v. 16, n. 32, p. 3601-3615, 2010.

PAVIA, C. S. Expression of cell-mediated antimicrobial immunity by mouse trophoblast monolayers. J. Infect. Dis., v. 147, n. 6, p. 1006-1010, 1983.

PERRICONE, C.; DE CAROLIS, C.; PERRICONE, R. Pregnancy and autoimmunity: a common problem. Best. Pract. Res. Clin. Rheumatol., v. 26, n. 1, p. 47-60, 2012.

PICCINNI, M. P.; MAGGI, E.; ROMAGNANI, S. Role of hormone-controlled T-cell cytokines in the maintenance of pregnancy. Biochem. Soc. Trans., v. 28, n. 2, p. 212-215, 2000.

POLLAK, N.; STERNS, T.; ECHTENACHER, B.; MÄNNEL, D. N. Improved resistance to bacterial superinfection in mice by treatment with macrophage migration inhibitory factor. Infect. Immun., v. 73, p. 6488-6489, 2005.

PLAISIER, M. Decidualisation and angiogenesis. Best Pract. Res. Clin. Obstet. Gynaecol., v. 25, n. 3, p. 259-271, 2011.

POWIS, G.; BONJOUKLIAN, R.; BERGGREN, M. M.; GALLEGOS, A.; ABRAHAM, R.; ASHENDEL, C.; ZALKOW, L.; MATTER, W. F.; DODGE, J.; GRINDEY, G. Wortmannin, a potent and selective inhibitor of phosphatidylinositol-3-kinase. Cancer Res., v. 54, n. 9, p. 2419-2423, 1994.

PRINS, J. R.; FAAS, M. M.; MELGERT, B. N.; HUITEMA, S.; TIMMER, A.; HYLKEMA, M. N.; ERWICH, J. J. Altered expression of immune-associated genes in first-trimester human decidua of Pregnancies later complicated with hypertension or foetal growth restriction. Placenta, v. 33, n. 5, p. 453-455, 2012.

RAGHUPATHY, R. Th1-type immunity is incompatible with successful pregnancy. Immunol. Today., v. 18, n. 10, p. 478-482, 1997.

RESTALL, B. J.; BINDON, B. M. The timing and variation of pre-implantation events in the mouse. J. Reprod. Fertil, v. 24, n. 3, p. 423-426, 1971. 
ROBERTSON, S. A. GM-CSF regulation of embryo development and pregnancy. Cytokine Growth Factor Rev., v. 18, n. 3-4, p. 287-298, 2007.

RODE, L.; KLEIN, K.; LARSEN, H.; HOLMSKOV, A.; ANDREASEN, K. R.; ULDBJERG, N.; RAMB, J.; BODKER, B.; SKIBSTED, L.; SPERLING, L.; HINTERBERGER, S.; KREBS, L.; ZINGENBERG, H.; WEISS, E. C.; STROBL, I.; LAURSEN, L.; CHRISTENSEN, J. T.; SKOGSTRAND, K.; HOUGAARD, D. M.; KRAMPL-BETTELHEIM, E.; ROSTHOJ, S.; VOGEL, I.; TABOR, A. Cytokines and the risk of preterm delivery in twin pregnancies. Obstet. Gynecol., v. 120, n. 1, p. 6068, 2012.

ROGER, T.; DAVID, J.; GLAUSER, M. P.; CALANDRA, T. MIF regulates innate immune responses through modulation of toll-like receptor 4. Nature, v. 414, p. 920924, 2001.

RONG, Y.; DISTELHORST, C. W. Bcl-2 protein family members: versatile regulators of calcium signaling in cell survival and apoptosis. Annu. Rev. Physiol., v. 70, p. 7391, 2008.

RUTANEN, E. M. Cytokines in reproduction. Ann. Med., v. 25, n. 4, p. 343-347, 1993.

SANDOVICI, I.; HOELLE, K.; ANGIOLINI, E.; CONSTÂNCIA, M. Placental adaptations to the maternal-fetal environment: implications for fetal growth and developmental programming. Reprod. Biomed. Online, v. 25, n. 1, p. 68-89, 2012.

SATO, A.; UINUK-OOL, T. S.; KURODA, N.; MAYER, W. E.; TAKEZAKI, N.; DONGAK, R.; FIGUEROA, F.; COOPER, M. D.; KLEIN, J. Macrophage migration inhibitory factor (MIF) of jawed and jawless fishes: implications for its evolucionary origin. Dev. Comp. Immunol., v. 27, p. 401-412, 2003.

SCHWARTZ, V.; LUE, H.; KRAEMER, S.; KORBIEL, J.; KROHN, R.; OHL, K.; BUCALA, R.; WEBER, C.; BERNHAGEN, J. A functional heteromeric MIF receptor formed by CD74 and CXCR4. FEBS Lett., v. 583, n. 17, p. 2749-2757, 2009.

SHI, X.; LENG, L.; WANG, T.; WANG, W.; DU, X.; LI, J.; MCDONALD, C.; CHEN, Z.; MURPHY, J. W.; LOLIS, E.; NOBLE, P.; KNUDSON, W.; BUCALA, R. CD44 is the signaling component of the macrophage migration inhibitory factor-CD74 receptor complex. Immunity, v. 25, n. 4, p. 595-606, 2006.

SONG, G.; OUYANG, G.; BAO, S. The activation of Akt/PKB signaling pathway and cell survival. J. Cell. Mol. Med., v. 9, n. 1, p. 59-71, 2005.

STAMBOLIC, V.; SUZUKI, A.; DE LA POMPA, J. L.; BROTHERS, G. M.; MIRTSOS, C.; SASAKI, T.; RULAND, J.; PENNINGER, J. M.; SIDEROVSKI, D. P.; MAK, T. W. Negative regulation of $\mathrm{PKB} / \mathrm{Akt}$-dependent cell survival by the tumor suppressor PTEN. Cell, v. 95, n. 1, p. 29-39, 1998.

STARLETS, D.; GORE, Y.; BINSKY, I.; HARAN, M.; HARPAZ, N.; SHVIDEL, L.; BECKER-HERMAN, S.; BERREBI, A.; SHACHAR, I. Cell-surface CD74 initiates a 
signaling cascade leading to cell proliferation and survival. Blood, v. 107, n. 12, p. 4807-4816, 2006.

SUZUKI, H.; NISHIHIRA, J.; KOYAMA, Y.; KANAGAWA, H. The role of macrophage migration inhibitory factor in pregnancy and development of murine embryos. Biochem. Mol. Biol. Int., v. 38, n. 2, p. 409-416, $1996 a$.

SUZUKI, H.; KANAGAWA, H.; NISHIHIRA, J. Evidence for the presence of macrophage migration inhibitory factor in murine reproductive organs and early embryos. Immunol. Lett., v. 51, n. 3, p. 141-147, 1996 b.

TACHI, S.; TACHI, C.; LINDNER, H. R. Ultrastructural features of blastocyst attachment and trophoblastic invasion in the rat. J. Reprod. Fertil., v. 21, n. 1, p. 37$56,1970$.

TANG, B.; GULLER, S.; GURPIDE, E. Mechanisms involved in the decidualization of human endometrial stromal cells. Acta Eur. Fertil., v. 24, n. 5, p. 221-223, 1993.

THOMAS, T. Distribution of alpha 2-macroglobulin and alpha 1-acid glycoprotein mRNA shows regional specialization in rat decidua. Placenta, v. 14, n. 4, p. 417-428, 1993.

TODROS, T.; BONTEMPO, S.; PICCOLI, E.; IETTA, F.; ROMAGNOLI, R.; BIOLCATI, M.; CASTELLUCCI, M.; PAULESU, L. Increased levels of macrophage migration inhibitory factor (MIF) in preeclampsia. Eur. J. Obstet. Gynecol. Reprod. Biol., v. 123, n. 2, p. 162-166, 2005.

VASSILIADIS, S.; RANELLA, A.; PAPADIMITRIOU, L.; MAKRYGIANNAKIS, A.; ATHANASSAKIS, I.Serum levels of pro- and anti-inflammatory cytokines in nonpregnant women, during pregnancy, labour and abortion. Mediators Inflamm., v. 7, n. 2, p. 69-72, 1998.

VIGANÒ, P.; CINTORINO, M.; SCHATZ, F.; LOCKWOOD, C. J.; ARCURI, F. The role of macrophage migration inhibitory factor in maintaining the immune privilege at the fetal-maternal interface. Semin. Immunopathol., v. 29, n. 2, p. 135-150, 2007.

VIVANCO, I.; SAWYERS, C. L. The phosphatidylinositol 3-Kinase AKT pathway in human cancer. Nat. Rev. Cancer., v. 2, n. 7, p. 489-501, 2002.

VLAHOS, C. J.; MATTER, W. F.; HUI, K. Y.; BROWN, R. F. A specific inhibitor of phosphatidylinositol 3-kinase, 2-(4-morpholinyl)-8-phenyl-4H-1-benzopyran-4-one (LY294002). J. Biol. Chem., v. 269, n. 7, p. 5241-5248, 1994.

WELSH, A. O.; ENDERS, A. C. Trophoblast-decidual cell interactions and establishment of maternal blood circulation in the parietal yolk sac placenta of the rat. Anat. Rec., v. 217, n. 2, p. 203-219, 1987.

WISTOW, G. J.; SHAUGHNESSY, M. P.; LEE, D. C.; HODIN, J.; ZELENKA, P. S. A macrophage migration inhibitory factor is expressed in the differentiating cells of the eye lens. Proc. Natl. Acad. Sci., v. 90, p. 1272-1275, 1993. 
XIE, X. F.; ZHAN, Y.; YE, Y. H.; LI, C.; ZHANG, Y. Expression of macrophage migration inhibitory factor and CD74 in preeclamptic placenta and its correlation with preeclampsia. Zhonghua Fu Chan Ke Za Zhi. v. 45, n. 4, p. 278-282, 2010.

XIE, L.; QIAO, X.; WU, Y.; TANG, J. Arrestin1 Mediates the Endocytosis and Functions of Macrophage Migration Inhibitory Factor. PLoS One., v. 25, 6, n 1, p. e16428, 2011.

YANG, J.; CRON, P.; GOOD, V. M.; THOMPSON, V.; HEMMINGS, B. A.; BARFORD, D. Crystal structure of an activated Akt/protein kinase B ternary complex with GSK3-peptide and AMP-PNP. Nat. Struct. Biol., v. 9, n. 12, p. 940-944, 2002.

YANG, L.; DAN, H. C.; SUN, M.; LIU, Q.; SUN, X. M.; FELDMAN, R. I.; HAMILTON, A. D.; POLOKOFF, M.; NICOSIA, S. V.; HERLYN, M.; SEBTI, S. M.; CHENG, J. Q. Akt/protein kinase B signaling inhibitor-2, a selective small molecule inhibitor of Akt signaling with antitumor activity in cancer cells overexpressing Akt. Cancer Res., v. 64, n. 13, p. 4394-4399, 2004.

YANG, Y.; ZOU, L.; LI, M.; ZHAO, Y. CXCL12/CXCR4 expression in trophoblasts takes part in materno-fetal immune tolerance and vascular remodeling. J. Huazhong Univ. Sci. Technolog Med. Sci., v. 26, n. 4, p. 466-468, 2006.

YOON, S. O.; KIM, M. M.; PARK, S. J.; KIM, D.; CHUNG, J.; CHUNG, A. S. Selenite suppresses hydrogen peroxide-induced cell apoptosis through inhibition of ASK1/JNK and activation of PI3-K/Akt pathways. FASEB J., v. 16, n. 1, p. 111-113, 2002.

ZERNECKE, A.; BERNHAGEN, J.; WEBER, C. Macrophage migration inhibitory factor in cardiovascular disease. Circulation, v. 117, n. 12, p. 1594-1602, 2008.

ZHOU, W. H.; DU, M. R.; DONG, L.; YU, J.; LI, D. J. Chemokine CXCL12 promotes the cross-talk between trophoblasts and decidual stromal cells in human firsttrimester pregnancy. Hum. Reprod. v. 23, n. 12, p. 2669-2679, 2008.

ZICARI, A.; TICCONI, C.; IETTA, F.; BELMONTE, A.; BECHI, N.; REALACCI, M.; DI VITO, M.; ARCURI, F.; RUSSO, M.; PICCIONE, E.; PAULESU, L. Macrophage migration inhibitory factor-nitric oxide interaction in human fetal membranes at term pregnancy. J. Soc. Gynecol. Investig., v. 13, n. 4, p. 263-270, 2006.

ZORN, T. M.; DE OLIVEIRA, S. F.; ABRAHAMSOHN, P. A. Organization of intermediate filaments and their association with collagen-containing phagosomes in mouse decidual cells. J. Struct. Biol., v. 103, n. 1, p. 23-33, 1990.

ZORN, T. M.; BIJOVSKY, A. T.; BEVILACQUA, E. M.; ABRAHAMSOHN, P. A. Phagocytosis of collagen by mouse decidual cells. Anat. Rec., v. 225, n. 2, p. 96100, 1989. 
ZORN, T. M.; BEVILACQUA, E. M.; ABRAHAMSOHN, P. A. Collagen remodeling during decidualization in the mouse. Cell Tissue Res., v. 244, n. 2, p. 443-448, 1986. 